\title{
Update on GPCR-based targets for the development of novel antidepressants
}

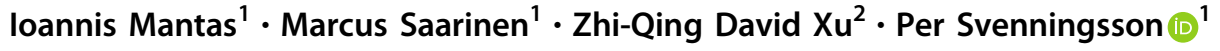 \\ Received: 5 June 2020 / Revised: 22 January 2021 / Accepted: 25 January 2021 / Published online: 15 February 2021 \\ (c) The Author(s) 2021. This article is published with open access
}

\begin{abstract}
Traditional antidepressants largely interfere with monoaminergic transport or degradation systems, taking several weeks to have their therapeutic actions. Moreover, a large proportion of depressed patients are resistant to these therapies. Several atypical antidepressants have been developed which interact with G protein coupled receptors (GPCRs) instead, as direct targeting of receptors may achieve more efficacious and faster antidepressant actions. The focus of this review is to provide an update on how distinct GPCRs mediate antidepressant actions and discuss recent insights into how GPCRs regulate the pathophysiology of Major Depressive Disorder (MDD). We also discuss the therapeutic potential of novel GPCR targets, which are appealing due to their ligand selectivity, expression pattern, or pharmacological profiles. Finally, we highlight recent advances in understanding GPCR pharmacology and structure, and how they may provide new avenues for drug development.
\end{abstract}

Major depressive disorder (MDD) or Major Affective Disorder is a severe psychiatric disorder affecting over 200 million people worldwide [1] The life-time depression risk is $15-18 \%$ and is higher in women than men [1]. MDD is often life-threatening due to the illness itself with a high suicide rate and as consequence of co-morbidities, such as drug abuse disorders and cardiovascular disease. MDD is commonly defined by the two major diagnostic classification systems: the Diagnostic and Statistical Manual of Mental Disorders or International Classification of Diseases. It is based on the presence of a certain number of signs and symptoms, including feelings of guilt, hopelessness, dysphoria, cognitive dysfunction, persistent sleep, and appetite abnormalities. However, categorical symptom-based disorder diagnoses often suffer from problems with heterogeneity

These authors contributed equally: Ioannis Mantas, Marcus Saarinen

$\triangle$ Per Svenningsson

Per.Svenningsson@ki.se

1 Department of Clinical Neuroscience, Karolinska Institute, Stockholm, Sweden

2 Department of Neurobiology, Beijing Key Laboratory of Neural Regeneration and Repair, Beijing Institute for Brain Disorders, Capital Medical University, Beijing, China because of the varied neurobiological mechanisms whereby people can qualify for a diagnosis. Moreover, patients who meet criteria for one mental disorder often tend to meet criteria for other mental disorders. Such co-morbidities can complicate the choice of therapy. There are indeed several alterations in brain circuitries, neuronal networks, and molecular pathways associated with MDD resulting in neurotransmitter and neuropeptide alterations, maladaptive neuroplasticity, hypothalamus-pituitary-adrenal (HPA) axis dysfunction, abnormal immune system responses, and circadian arrhythmicity. There are currently many different approaches to treat MDD. In this review we discuss the roles of $\mathrm{G}$ protein coupled receptors (GPCRs) to mediate actions of existing antidepressant therapies. Based on recent insights into the biology of GPCRs, we then discuss new avenues for optimized usage of GPCRs currently targeted by antidepressants. Finally, the review discusses the therapeutic potential of novel GPCR targets which are localized in brain circuitries implicated in MDD pathophysiology.

\section{Brain regions and circuitries involved in MDD}

There is a vast body of data implicating certain brain structures in MDD. Post-mortem analyses and MRI studies have reported morphological changes in MDD patients, 
Fig. 1 Receptors that are targeted by established treatments in brain regions involved in MDD. In the center, it is depicted the human brain together with different brain areas that are involved in the symptomatology of MDD. Each circle panel shows the neuronal types that have been found to affect depressive-like behavior together with the receptors that they express. GABA neurons/ terminals: gray, glutamate neurons/terminals: blue, DA neurons/terminals: pink, 5-HT neurons/terminals: cyan, $\mathrm{NE}$ neurons/terminals: yellow, cholinergic neurons/terminals: orange. VTA ventral tegmental area, mPFC medial prefrontal cortex, LHA lateral

hypothalamic area, NAc nucleus accumbens, DR dorsal raphe, LHb lateral habenula, RMTg rostromedial tegmentum, ACC anterior cingulate cortex, BA25 Brodmann area 25, HF hippocampal formation, Amy amygdala, dMSN direct medium spiny neuron, iMSN indirect medium spiny neuron, CIN cholinergic interneuron, GIN GABAergic interneuron, Py pyramidal, Glu glutamate, DA dopamine, 5-HT serotonin, 5HTT serotonin transporter, NET norepinephrine transporter, MAOA/B monoamine oxidase $\mathrm{A} / \mathrm{B}$, TMS transcranial magnetic stimulation.
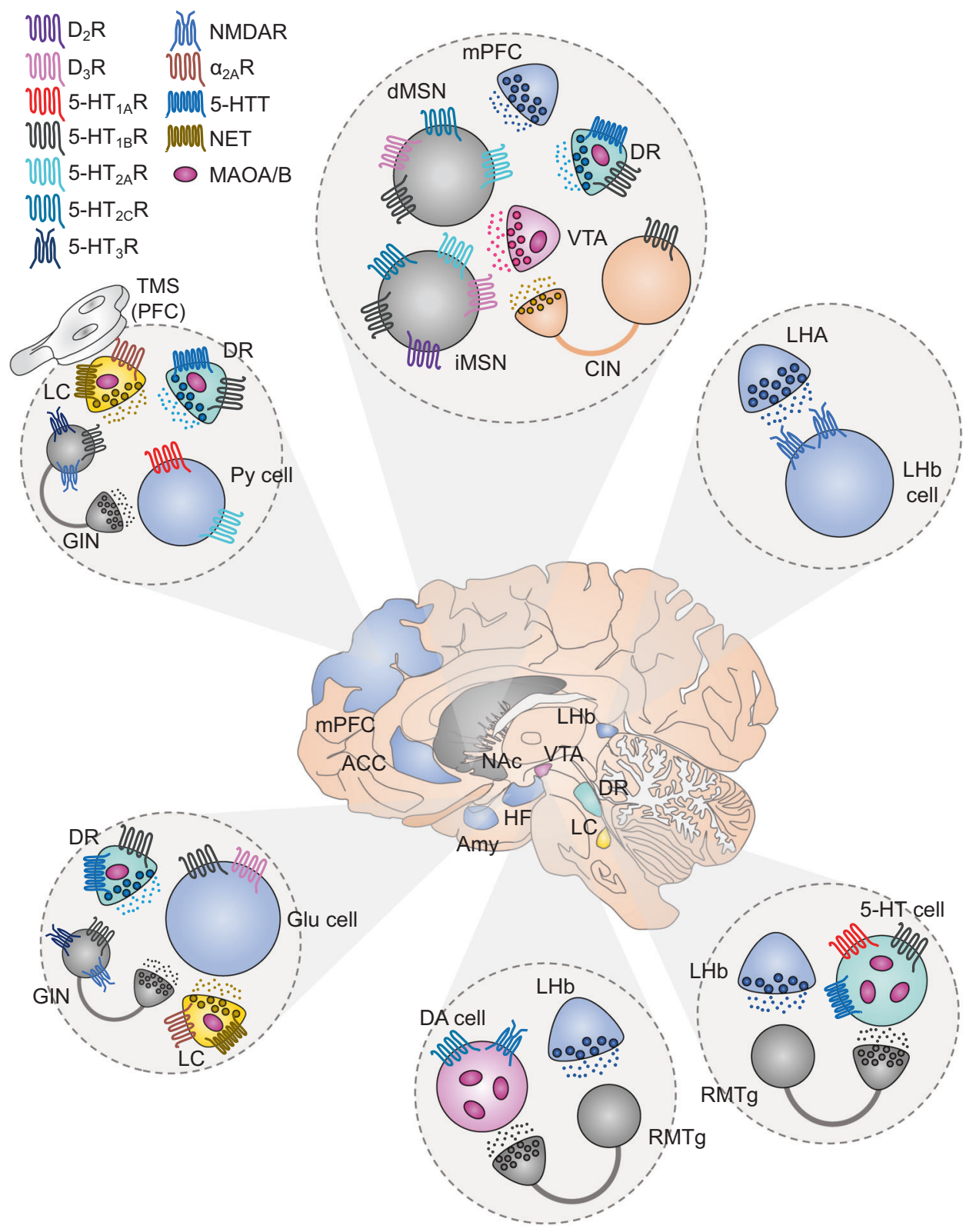

both in neurons and glia, in several subcortical and cortical brain regions including the hippocampus/subiculum, amygdala, nucleus accumbens (NAc), and prefrontal cortex (PFC) (Fig. 1) [2, 3]. The decrease in hippocampal volume is directly proportional to the number and duration of depressive episodes, especially in early-onset $\operatorname{MDD}[4,5]$. This volume reduction seems to be related to prolonged increased levels of cortisol, which may relate to the fact that the hippocampus is the brain region with the highest levels of glucocorticoid receptors [6]. Accordingly, numerous studies, not least in animal models, have shown that chronic administration of glucocorticoids leads to changes in mood and cognition [6]. Exposure to prolonged stress and/or stressful events can lead to persistently increased responsivity of the HPA axis. [6]. The activity of the HPA axis is fundamental to the control of several body functions, including metabolism, the immune system, and brain functions such as neuronal survival, neurogenesis, sleep regulation, and memory acquisition. The HPA axis activity is governed by different hormones: corticotropin-releasing hormone (CRH) and vasopressin (AVP) from the hypothalamus; adrenocorticotrophic hormone (ACTH) from the anterior pituitary; and glucocorticoids from the adrenal cortex. By acting via the two GPCRs, CRH1 and V1b, increased levels of CRH and AVP will lead to increased ACTH that will, in turn, increase the secretion of glucocorticoids. Glucocorticoids have a negative feedback action on the HPA axis. A significant number of depressive patients show increased levels of glucocorticoids and a lack of feedback suppression of the HPA axis by 
glucocorticoids. Antagonism of nuclear glucocorticoid receptors, particularly by mifepristone, has been evaluated in psychotic depression [7]. Likewise, antagonists at the, $\mathrm{CRH} 1$ and $\mathrm{V} 1 \mathrm{~b}$ receptors have been developed as putative antidepressants $[8,9]$. In depressive patients, memory formation is skewed towards negative events; this is known as negative bias. Negative bias is characterized by an enhanced focus on negative stimulus, enhanced attention towards potentially threatening stimuli, and the attribution of negative emotional value to environmental stimuli that are considered to have neutral valance by healthy individuals [10]. Negative bias-related memories does not only involve the hippocampus, but also amygdala, anterior cingulate cortex (ACC), PFC, and ventral striatum (i.e. NAc).

There is also a lot of evidence of volume reductions of cortical areas in MDD which correlates to disease progression and therapy responsivity [4] In particular, structural MRI has shown volume reductions in medial PFC and ACC [4]. Transmagnetic stimulation (TMS), which is gaining acceptance as an antidepressant therapy, is often applied to these frontal cortical regions [11]. It has been observed that some frontal cortical regions (including the subgenual cingulate cortex or Brodmann area 25) are metabolically overactive in treatment-resistant depression [12]. Accordingly, this area was targeted with deep brain stimulation (DBS), which is a method where high frequency electrical stimulation is transmitted to specific CNS target areas through an implanted brain electrode [12]. This resulted in a striking and sustained remission of depression in some previously treatment-resistant patients in an open study [12]. However, there is no published randomized clinical trial (RCT) to confirm this antidepressant effect. It seems that patient selection based on multiple parameters, including diffusion tensor imaging and tractography identification of circuitries, and optimized protocols are necessary to improve response and clinical utility of DBS in MDD [13].

Altered excitatory neurotransmission from hippocampus/ subiculum and frontal cortex alters the activity of outputs regions. There is accumulating evidence that NAc plays an important role in integrating excitatory neurotransmission from hippocampus/subiculum and frontal cortex to mediate emotionally dysregulated behaviors in MDD [14]. Deficit excitatory inputs to the NAc has been reported to result in reduced activity and overall volume in MDD patients [15] Likewise, repeated stress causes a volume reduction in the NAc of rodents [16] An observational study showed an antidepressant effect of DBS in the NAs [17], but a subsequent RCT failed to replicate this finding [18].

Technological advances in anatomical and functional dissection of neural circuits in animals have identified brain structures that actively regulate mood. Using optogenetics, it has also been described that the reward-brain state is mediated by the feedback loop between the PFC, NAc, and thalamus [19]. One of the major pathways that have been repeatedly shown to display antidepressant-like properties, is the ventral tegmental area (VTA)- NAc dopaminergic (DA) pathway $[19,20]$. Phasic optogenetic activation of this pathway elicits rapid antidepressant effects [21]. In accordance, optogenetic activation of the VTA innervating GABAergic neurons located in rostromedial tegmental nucleus (RMTg), disrupts reward consumption [22, 23]. Another region that has gained a lot of attention due to its strong relationship with aversion and depressive-like states, is the lateral habenula ( $\mathrm{LHb})$ [24-27]. This brain region stimulates RMTg which in turn inhibits VTA DA neurons $[28,29]$. It has been shown that optogenetic activation of excitatory LHb afferents from lateral hypothalamic area or $\mathrm{LHb}$ neurons themselves, produces a robust avoidance behavior [30]. Accordingly, DBS of the LHb can reverse depressive-like behaviors in rodents [25], reinforcing a role of the LHb in depression. Furthermore, optogenetic targeting of projections from medial PFC to dorsal raphe nucleus (DRN) will control mobility in the forced swim test, while targeting projections from basolateral amygdala to NAc produces appetitive or aversive response, depending on the type of stimulus [31].

\section{Neurotransmitters involved in MDD}

The current antidepressant medications are targeting a variety of neurotransmitter systems in the brain. The main five classes of antidepressant include selective serotonin (5HT) reuptake inhibitors (SSRIs), serotonin-norepinephrine (NE) reuptake inhibitors (SNRIs), tricyclic antidepressants (TCAs), monoamine oxidase inhibitors (MAOIs), and atypicals [32]. The first four classes are indirectly enhancing monoamine neurotransmitters, while the latter mainly act as monoamine receptor ligands [32]. Due to the uprising of ketamine which modulates glutamatergic neurotransmission as fast-acting antidepressant, we will divide the antidepressant drugs according to the neurotransmitter system that they affect (monoamine-based versus glutamate-based) [32].

As detailed below, the monoaminergic nuclei, VTA (DA), DRN (5-HT), and locus coeruleus (LC) (NE), send widespread projections to the hippocampus, amygdala, ACC, PFC, and NAc and modulate their functions [33]. A critical role of monoamines in depression was discovered more than 60 years ago when it was found that iproniazid, a drug developed against tuberculosis, was found to exhibit antidepressant properties via inhibition of MAO [34]. During the same period, the putative antipsychotic agent, imipramine, showed antidepressant properties and was approved as the first tricyclic drug against depression [35]. 
Pioneering work showed that imipramine could counteract NE uptake into presynaptic neurons [36]. It was later found that the antidepressant desipramine, a metabolite of imipramine, is a selective NE reuptake inhibitor. This finding, together with data showing lowered activity of NEergic neurons in depression, led to the catecholamine hypothesis of depression [37]. NEergic neurons from the LC innervate mainly the PFC, amygdala, hippocampus, and hypothalamus $[38,39]$. It was subsequently found that several tricyclic drugs for depression also inhibit 5-HT reuptake, and a 5-HT hypothesis of depression was conceived [40]. Direct in situ detection of 5-HT and its rate-limiting enzyme, tryptophan hydroxylase 2, have demonstrated that 5HTergic terminals are enriched in PFC, hippocampus, amygdala, hypothalamus and basal ganglia output structures [38, 41, 42]. These axonal fields stem from the DRN [42]. Currently, agents that selectively inhibit the reuptake of either NE (e.g. reboxetine) or 5-HT (e.g. fluoxetine, paroxetine, sertraline, and citalopram), or both (e.g. venlafaxine and duloxetine) are commonly used as drugs for depression and anxiety [43]. Bupropion, a NE and DA reuptake inhibitor, is an antidepressant drug with energizing and mood-elevating properties acting on the mesolimbic VTA-NAc and VTA-PFC DA pathways [43].

It has been established that the mesolimbic VTA-NAc connection is a crucial regulator of mood [20] Dopaminoceptive cells in the dorsal as well as ventral striatum (i.e. NAc) are so-called medium spiny neurons (MSNs) and release GABA as a neurotransmitter [44]. In the dorsal striatum, which receives dopaminergic input from substantia nigra and critically regulates locomotion, MSNs are well-divided in two equally large populations named direct medium spiny neurons (dMSNs) or indirect medium spiny neurons (iMSNs) [44]. dMSNs express high levels of DA $D_{1}$ receptors, whereas iMSNs express $D_{2}$ receptors, respectively [45]. The dMSN-iMSN principle is maintained in the NAc, but there is a significant portion of MSNs that express both $\mathrm{D}_{1}$ and $\mathrm{D}_{2}$ or $\mathrm{D}_{3}$ receptors [46-48]. These cells constitute a morphologically distinct MSN type which does not follow the classical dogma of striatal direct and indirect pathway [48]. Nevertheless, selective dMSN and iMSN activation results in opposing functions and show antidepressant and depressive-like properties, respectively [49]. Moreover, recent evidence has shown that both dMSNs and iMSNs encode reward and aversion but with differential action plans [50].

Over the recent years, the understanding of the pathophysiology of MDD has undergone a conceptual shift from monoamine-based models focused on monoaminergic synaptic neurotransmission in localized brain regions; to more dynamic disease models of altered synaptic and neural plasticity in neuronal brain circuitry with a broad focus on not only monoamines but also the excitatory and inhibitory neurotransmitters, glutamate and GABA [51] While dysregulated monoamine neurotransmission may be sufficient to cause depression it has become evident that it is not a necessary condition; converging evidence indicates that changes in glutamatergic signaling, neuropeptides, neurotrophic factors, and brain plasticity play important roles. There is recent data that there is lower synaptic density, measured by a SV2A PET ligand, in hippocampal and cortical networks of MDD patients [52]. In this context, it is interesting to note that tianeptine, an atypical drug for depression, promotes synaptic plasticity by potentiating glutamate AMPA receptor function [53]. Moreover, it has also recently been demonstrated that tianeptine acts as a $\mu$ opioid receptor $(\mu \mathrm{OR})$ agonist to exert antidepressant actions [54].

Studies using magnetic resonance spectroscopy to measure the concentration of intra- and extracellular glutamate, glutamine, and GABA have shown changes in the glutamate system (for example, reduced levels of glutamine, the precursor of glutamate) in MDD patients [55-57]. The changes in glutamate levels in MDD have been reported to show regional differences [58]. A pharmacological link between glutamatergic neurotransmission and MDD was actually found more than 60 years ago when it was reported that D-cycloserine ameliorated depressive symptomatology [59]. It was later found that this effect may be due to partial agonism at the glycine recognition site of the glutamatergic NMDA receptors. As discussed below, several RCTs with the NMDA antagonist, ketamine, have been carried out in the past decade demonstrating a rapid antidepressant effect in MDD patients resistant to monoamine-based antidepressants [60].

\section{GPCR-mediated effects of approved monoamine-based antidepressants}

The eukaryotic repertoire for cell communication and signal transduction is largely mediated by several different receptor families with distinct mechanisms of activation and action. Members from the different receptor families have been implicated in MDD. They range from nuclear receptors, such as the glucocorticoid receptor, ligand-gated ion channels, such as the NMDA receptor, receptor tyrosine kinases, such as BDNF/TrkB, to GPCRs. GPCRs span over 800 members in the human genome and can be roughly divided into two groups; olfactory and nonolfactory [61]. Structurally, GPCRs are composed of a common foundation spanning seven helical transmembrane (TM) domains, with highly heterogenous amino and carboxyl termini [62]. GPCRs can be divided into six classes (A-F) with two newer additions accounting for taste and other receptors [63]. These groups can be further separated based on their 
pharmacological classification, such as if they bind nucleotides, lipids, amino acids, or biogenic amines. Importantly, they are typically expressed on the cell-surface plasma membrane. Upon activation, GPCRs undergo a conformational change typically involving large outward movements of TM 5 and 6 cytoplasmic tails. GPCRs act as guanosine nucleotide exchange factors which, upon activation, favor the switch of GDP for GTP on the G $\alpha$ of the inactive G $\alpha \beta \gamma$ heterotrimer [64]. The GTP bound complex undergoes rapid disassociation followed by separation of

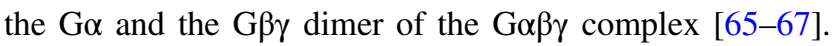
The G $\beta \gamma$ subunits can then directly interact with several signaling molecules such as G-protein inward rectifying potassium channels (GIRKs) and $\mathrm{Ca}^{2+}$ channels. Depending on the $\mathrm{G} \alpha$ that is recruited, various downstream signaling processes may occur $[66,68]$. A plethora of molecular pharmacology and careful investigation into GPCR: G $\alpha$ pairing has revealed that many receptors can signal via several Go's depending on variables such as ligand and cellular context [61, 69]. The signaling cascade is terminated starting with GPCR phosphorylation by Gprotein coupled receptor kinases which potentiates the recruitment of $\beta$-arrestins. $\beta$-arrestins sterically block further $\mathrm{G} \alpha$ interactions, and typically internalize the receptor, either recycling it back to the surface plasma membrane or forward the receptor for degradation [70].

GPCRs are appealing for pharmacological intervention and correspondingly serve as the targets for around 1/3rd of all FDA approved medications [71-73], due to several reasons; First, GPCRs act as signal transducers by typically binding an extracellular signal molecule, and respond by relaying the signal through complex cascades to the cell interior. This provides a therapeutic potential in altering the internal state of a target cell group without requiring membrane permeability of the molecule. Second, GPCRs are known to control or influence nearly every relevant physiological process from vision to vasoconstriction, which permits for direct pharmacological modulation of a specific, disease relevant process. Third, GPCRs are known to be activated by a myriad of different ligands, ranging from photons to peptides, which allows for a substantial chemical space in which to design therapeutic molecules to act on these receptors. Using X-ray crystallography or cryo$\mathrm{EM}$, recent breakthroughs have resulted in atomic resolution structures for more than 70 GPCRs in complex with ligands and intracellular effectors. This enables the identification of binding pockets and performance in silico library screening of small molecules towards GPCRs, providing faster and larger avenues towards drug discovery [74-76].

Monoaminergic neurotransmission is largely based on GPCR signaling. Since the major antidepressant classes affect the monoaminergic systems, they exert their actions either directly or indirectly through GPCRs. There is a delayed onset of therapeutic efficacy of monoamine-based antidepressants and the mechanism(s) underlying their antidepressant actions remain to be fully understood. There is evidence that the late onset therapeutic effects may be the outcome of transcriptional alterations in genes encoding proteins involved in synapse formation or neurogenesis $[20,77]$. There is also data suggesting an important role of altered levels and posttranslational modifications of proteins regulating synaptic plasticity and neuronal firing [78]. There are 14 5-HT receptors (13 which are GPCRs), 6 NE receptors and $5 \mathrm{DA}$ receptors. $5-\mathrm{HT}_{1 \mathrm{~A}}$ receptors are critical in regulating 5 -HT neurotransmission. The $5-\mathrm{HT}_{1 \mathrm{~A}}$ somatodendritic autoreceptor, which negatively controls 5-HT release, is an important target, since its blockade augments extracellular 5-HT levels [43], whereas postsynaptic 5$\mathrm{HT}_{1 \mathrm{~A}}$ receptors exert behavioral and neurogenic effects of fluoxetine [77]. Accordingly, vilazodone is a combined 5$\mathrm{HT}_{1 \mathrm{~A}}$ partial agonist and an SSRI, and is used for the treatment of depression [43]. Another compound that both inhibits 5-HT reuptake and targets 5-HT receptors is vortioxetine, which binds to $5-\mathrm{HT}_{1 \mathrm{~A}}$ (agonist, postsynaptic receptor selectivity), 5- $\mathrm{HT}_{1 \mathrm{~B}}$ (partial agonist), and $5 \mathrm{HT}_{7}$ (antagonist) receptors along with ionotropic 5- $\mathrm{HT}_{3}$ (antagonist) receptors. In addition to these 5-HT receptors, antagonism at $5-\mathrm{HT}_{2 \mathrm{C}}$ receptors plays an important role in the antidepressant actions of mirtazapine and agomelatine [43, 79]. Agomelatine combines 5- $\mathrm{HT}_{2 \mathrm{C}}$ receptor antagonism with agonism at another GPCR, the melatonin $\mathrm{MT}_{1}$ receptor and has antidepressant properties, along with beneficial effects on sleep, due to the restoration of circadian rhythmicity. Mirtazapine is also a NEergic $\alpha_{2 \mathrm{~A}}$ autoreceptor antagonist and enhances fronto-cortical NEergic transmission to elevate mood.

Several studies have reported that $\mathrm{DA} \mathrm{D}_{2 / 3}$ agonists, some of which are used in the treatment of Parkinson's disease [80], exert antidepressant actions [81].

\section{Receptor-mediated actions of glutamate- based antidepressants}

In contrast to monoaminergic drugs, some compounds acting via glutamate receptors possess rapid antidepressant effects. It has been reported that glutamatereducing agents, such as riluzole and lamotrigine, exert antidepressant actions by lowering extracellular levels of glutamate [82-84]. Moreover, it has been established that blockade of NMDA receptors by a single injection of the negative allosteric modulator (NAM) ketamine causes a rapid (within hours) and long (weeks) antidepressant effect $[57,60,85]$. This is a breakthrough in the field, but the psychotomimetic, anaesthetic, amnestic, and addictive properties of ketamine preclude usage on a larger scale. 
Intense research is focused on finding alternative ways of interfering with glutamate neurotransmission to achieve fast antidepressant actions without severe side effects.

Mapping of pathophysiological processes involving NMDAR is necessary to fully elucidate effects of ketamine. Due to the widespread expression of NMDAR throughout the CNS, the neuroanatomical target(s) and circiutries that mediates ketamine's antidepressant effects is still poorly understood. Nevertheless, the ability of ketamine to block the firing of LHb glutamatergic projection neurons $[86,87]$ and GABAergic prefrontal cortical interneurons [88-90], appears important for its antidepressant properties. Several studies have been examining the role of different NMDA receptor subunits in antidepressant responses. NMDAR function is dependent on the subunit composition of these receptors, which are heteromeric assemblies of at least one $\mathrm{NR}_{1}$ - and other $\mathrm{NR}_{2}-\left(\mathrm{NR}_{2 \mathrm{~A}^{-} \mathrm{D}}\right)$ subunits. The functional and pharmacological properties of NMDAR are determined by their $\mathrm{NR}_{2}$ subunits and studies have examined the role of the individual $\mathrm{NR}_{2}$ subunits in relation to depression-like

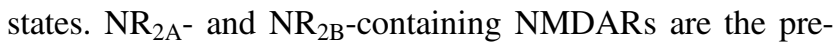
dominant complexes in forebrain regions mediating emotional behaviors. Antagonists specific to the $\mathrm{GluN}_{2 \mathrm{~B}}$-subunit are available and have shown that blockade of $\mathrm{GluN}_{2 \mathrm{~B}}$ is sufficient to induce antidepressant-like effects of NMDAR antagonists in rodents $[88,91,92]$. However, at the same time, selective deletion of $\mathrm{GluN}_{2 B}$ subunit in somatostatin positive GABA interneurons in mPFC abolishes the rapid antidepressant actions of ketamine [89]. It is important to remember that no human clinical studies have, so far, replicated the full spectrum of robust, rapid, and sustained antidepressant actions observed with ketamine using alternative drugs that directly inhibit NMDAR function [93].

Even though there are several studies which provide evidence that ketamine's antidepressant properties stem from its ability to antagonize NMDARs, there is growing evidence supporting that ketamine's NMDAR-independent actions may also play a role in alleviating depressive symptoms. Preclinical studies indicate that the ketamine metabolite $(2 R, 6 R)$-hydroxynorketamine $((2 R, 6 R)$-HNK $)$ exerts antidepressant action with fewer side effects than ketamine by potentiating AMPA receptors [94]. This study reports that ketamine's NMDAR-dependent actions produce the side effects of the drug, such as abuse liability demonstrated by self-administration, psychotomimetic actions in the prepulse inihibition paradigm and motor icoordination, while the $(2 R, 6 R)$-HNK-induced AMPAR activation is responsible for the antidepressant actions [94]. Recent data indicate that metabotropic glutamate receptors are also involved in antidepressant actions of ketamine and $(2 R, 6 R)$ HNK. In particular, combined subeffective doses of an $\mathrm{mGlu}_{2 / 3}$ receptor antagonist and $(2 R, 6 R)$-HNK or ketamine synergistically exerted antidepressant-relevant actions
$[95,96]$. These studies illustrates that targeting metabotropic glutamate receptors may achieve antidepressant effects. The evidence for depression treatment via modulation at mGluR's has actually been known for nearly two decades (for a thorough earlier review on the topic, refer to ref. [97]). There are eight metabotropic glutamate receptors and ligands acting at metabotropic glutamatergic 2,3 , or 5 receptors have shown antidepressant actions and allosteric modulators have entered clinical trials in MDD patients (see below).

\section{Current GPCR targets, new avenues}

\section{Biased ligands}

A dominating approach in modern drug discovery concerning ligand development for a target receptor is to selectively modulate, or fine tune its transduction mechanism, favoring one signaling pathway over another (see Fig. 2) [98]. This favoritism is often referred to as signaling bias or functional selectivity [99] (for more terms, see to [100]). The fundamental idea is that as many GPCRs are capable of coupling to different $\mathrm{G} \alpha$ subunits (and thus eliciting different cellular responses), different ligand profiles can be used to favor stabilizing receptor conformations for coupling to a specific intracellular mediator. The concept is not limited to G-protein:GPCR selectivity, but also applies to the degree of G-protein vs $\beta$-arrestin recruitment which a ligand may exhibit. This adds complexity to the historical model in which all agonists were thought to stabilize one receptor state, eliciting a signal via one concise pathway [100].

These concepts are valuable consequences for not only rational drug design, but furthermore expands our understanding of GPCRs, discounting them as binary switches and recognizes them as machineries capable of varied, ligand specific conformational changes resulting in a diverse set of outcomes [101]. These expanded outcomes also help us to understand the effects of already established pharmacological treatments on otherwise well characterized receptors.

The goal for any therapeutic agent would be to maximize its positive effects while mitigating negative side effects. Traditionally, the majority of observable side effects have been largely credited to unspecific interactions, resulting in the therapeutic agent activating either unwanted targets, or the target receptor in unwanted cell populations [102]. With the onset of signaling bias, we can now also expand the repertoire of an ideal compound from functional receptor and cell population selectivity, to maximize its properties along a specific signal transduction pathway. Owing to the current advances in structural biology and cell signaling 


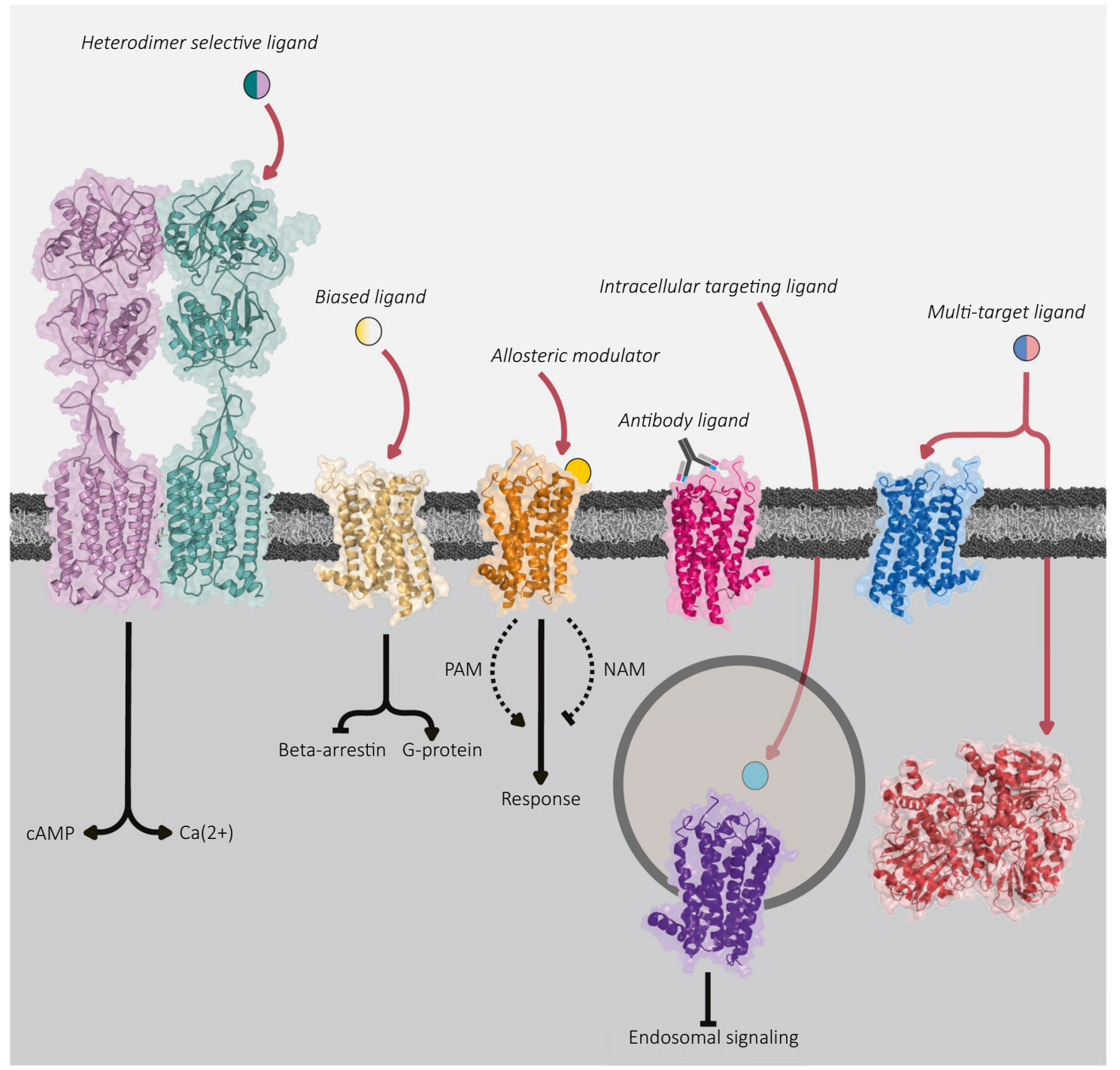

Fig. 2 Novel avenues of receptor targeting. Starting from left: A ligand which recognizes a specific dimer pair of receptors with a $\mathrm{GABA}_{\mathrm{B}}$ receptor as an example. Here, the extracellular region of $\mathrm{GABA}_{\mathrm{B} 1}$ binds the ligand and the second $\left(\mathrm{GABA}_{\mathrm{B} 2}\right)$ transmembrane receptor recruits $\mathrm{G}$-proteins for downstream signaling cascades. Biased ligands can be used to favor signaling along one signaling pathway while avoiding the other. Similarly, allosteric modulators may be used to regulate the endogenous agonist response, either in an excitatory

investigation techniques, the search and development of functionally selective ligands has become increasingly popular [103]. Perhaps the most well-known example is the $\mu \mathrm{OR}$, the main GPCR for morphine (from which the receptor derives its name [104]). Earlier studies suggested that the analgesic effects of the $\mu \mathrm{OR}$ can largely be ascribed to its potential to recruit and signal through $G \alpha_{i}$ proteins, whereas negative and potentially lethal side effects such as respiratory depression can be attributed to its $\beta$-Arrestin-2 signaling [105-107]. Critically, it needs to be mentioned that this phenomenon has also recently been revisited with challenging results $[108,109]$. However, the development
(PAM) or inhibitory (NAM) fashion. Likewise, antibody-based ligands have been demonstrated both in nature and in recent pharmacological screens to exert excellent target specificity. Specific receptor populations may also be targeted by focusing on intracellular targets such as with the neurokinin-1 receptor. Lastly, the development of rationally designed molecules targeting both a GPCR and an intracellular enzyme may modulate two distinct cellular processes inducing a greater therapeutic response form the drug.

of $\mu \mathrm{OR}$ agonists which would selectively signal through Gproteins and avoid $\beta$-arrestin- 2 recruitment garnered clinical interest [110] and the first biased ligand (Oliceridine) was approved by the FDA in 2020 .

Specificity has been a major hurdle for the development of pharmacological agents to target psychiatric disorders such as MDD, as the majority of conventionally available therapeutic targets recognize biogenic amines [111, 112]. The aminergic receptors unsurprisingly often share significant homology and conserved orthosteric binding pockets, a key culprit in the resulting amplified difficulty of developing specific, therapeutically feasible molecules [111]. 
Combining the complex task of designing a receptor selective ligand with that of a pathway specific consequence is by no means an easy task, but one that must be tackled to provide highly beneficial treatment options for depressive disorders. However, this combination of complexities also offers pharmacological versatility as receptors couple to specific intracellular signal transducers within specific cell populations [113, 114]. Ideally, this would imply that providing a molecule encouraging a specific conformational change leading to a precise second messenger coupling would improve the cell and region-specific targeting of the compound. Additionally, the conformational change underlying G-protein recruitment also alters GPCR ligand affinity; in an elegant study using nanobodies which could lock the $\beta 2$-adrenoreceptor either in a G-protein bound or an unbound state, the authors characterized the affinity of various compounds for the two receptor states [115]. Remarkably, it was also possible to derive compounds that could discriminate between the two states by over four orders of magnitude and highly G-protein biased compounds could be distinguished [115]. Utilizing such Gprotein nanobody mimetics to identify compounds with specificity not only towards G-protein coupling, but also receptor states and perhaps $\beta$-arrestin could be highly advantageous for limiting unintended effects of potential new therapeutics and increasing the accuracy of targeting specific cell populations.

The $5 \mathrm{HT}_{1 \mathrm{~A}}$ receptor has been well elucidated to serve as potential targets of biased ligands (for an in-depth review, see ref. [114]). The $5 \mathrm{HT}_{1 \mathrm{~A}}$ receptor is known to exist in two main populations, as autoreceptors in the raphe nuclei, and as postsynaptic heteroreceptors in the medial septum, PFC, and hippocampus. In the dorsal raphe, $\mathrm{G}_{\mathrm{\alpha i} 3}$ coupling has been shown, whereas $G_{\alpha 0}, G_{\alpha i 3}, G_{\alpha i 1}, G_{\alpha z}$ coupling has been reported in the hippocampus and cortex [116, 117]. Balanced targeting of $5 \mathrm{HT}_{1 \mathrm{~A}}$ is undesirable, as presynaptic activation inhibits 5-HT release whereas the postsynaptic receptor activation induces synaptic plasticity and neurogenesis [114]. Selective targeting of the postsynaptic heteroreceptor, $5 \mathrm{HT}_{1 \mathrm{~A}}$ population could thus provide an efficient therapeutic treatment for depression. As a result, a few selective $5 \mathrm{HT}_{1 \mathrm{~A}}$ agonists displaying ligand bias have been developed; F-15599 and F-13714 display ligand bias towards the postsynaptic heteroreceptors and presynaptic autoreceptors, respectively [118-120]. Although this phenomenon is one of regional bias, the authors indeed suggest that it is a direct result of separate affinities for different receptor confirmations (thus G-proteins) and the availability of population specific G-protein subtypes. Interestingly, recent in vivo studies show that, F-15599 improves pattern separation performance, exerts potent antidepressantlike effects and displays a low partiality to induce serotonergic syndrome behaviors $[119,121]$. Similarly, another $5 \mathrm{HT}_{1 \mathrm{~A}}$ ligand (HBK-17) with a preference for $\beta$ Arrestin signaling was recently reported to induce anxiolytic- and antidepressant-like behaviors in vivo [122].

Structure-based methods are invaluable to understand and leverage the key molecular components that underlie ligand-receptor relationships. Around 70 unique GPCR structures have been elucidated, a remarkable worldwide effort since the first high-resolution structure of rhodopsin solved some two decades ago [123]. Although that still leaves some 300 receptor structures to be deciphered, the existing data can and is intensely used to identify residues fundamental for receptor-ligand interactions, microswitches, and novel binding sites not just in the solved receptor, but in related GPCRs as well. Significant progress has been done on understanding the functional selectivity of the $5 \mathrm{HT}_{2 \mathrm{~A}}, 5 \mathrm{HT}_{2 \mathrm{~B}}$, and $5 \mathrm{HT}_{2 \mathrm{C}}$ receptors [124-127].

On their own, selective targeting of these receptors also holds promise; increasing evidence points to the potential of treating MDD with $5 \mathrm{HT}_{2 \mathrm{~A}}$ agonists such as psilocybin, the active ingredient in 'magic mushrooms' [128]. Accordingly, FDA has granted a breakthrough therapy designation towards psilocybin-assisted therapy for MDD, with earlier phase II clinical trials indicating encouraging results [129-131]. Although the mechanism behind this phenomenon is still under debate, we have recently gained some structural understanding of $5 \mathrm{HT}_{2 \mathrm{~A}}$ antagonism exerted by the second-generation antipsychotics risperidone and zotepine [124]. The structure of $5 \mathrm{HT}_{2 \mathrm{~A}}$ displays a conserved hydrophobic cleft surrounding the orthosteric binding pocket composed of key residues such as $\mathrm{Ile}^{3.40}$, and Phe $\mathrm{Ph}^{6.44}$ and $\operatorname{Trp}^{6.48}$ (Ballesteros-Weinstein numbering) of the P-I-F trigger motif which displayed significantly reduced activities when mutated. Interestingly, this same cleft is observed in an inverse agonist structures of the related $5 \mathrm{HT}_{2 \mathrm{C}}$ receptor, but not in its agonist bound state. This helps to highlight the importance of ligand interactions with these residues to promote the inactive conformation, which should be taken into consideration when designing potential new agonists at $5 \mathrm{HT}_{2}$ receptors. Additionally, the structure reveals a side-extended cavity connecting the plasma membrane with the orthosteric binding pocket with less conserved hydrophobic residues including a Gly ${ }^{5.42}$, a unique structural detail shared only between $5 \mathrm{HT}_{2}$ receptors. Both risperidone and zotepine maintain the highly conserved aminergic salt-bridge with $\mathrm{Asp}^{3.32}$, and the binding of risperidone also relies on a more unusual residue, $\mathrm{Val}^{7.39}$. Intriguingly, the same is observed also with the parent molecule of risperidone, in the ritanserin bound structure of the $5 \mathrm{HT}_{2 \mathrm{C}}$ receptor. Recently, the structures of LSD bound $5 \mathrm{HT}_{2 \mathrm{~A}}$ and more strikingly, the $25-\mathrm{CN}-\mathrm{NBOH}$ bound $5 \mathrm{HT}_{2 \mathrm{~A}}-\mathrm{G}_{\alpha q}$ structures were also elucidated [132]. Once again, large outward shifts of TM5 and 6 are seen, while in the $5 \mathrm{HT}_{2 \mathrm{~A}}-\mathrm{G}_{\alpha q}$ structure, a smaller inward shift of 
TM7 is observed. Trp ${ }^{6.48}$ is observed to make hydrophobic contact with $25-\mathrm{CN}-\mathrm{NBOH}$ coinciding with the TM6 outward movement and the displacement of Phe ${ }^{6.44}$ of the P-I-F trigger motif. Several critical residues for $\mathrm{G}_{\alpha q}$ signaling such as $\mathrm{Arg}^{\mathrm{ICL} 2}$ and $\mathrm{Asn}^{2.37}$ were discovered, and $\mathrm{Asn}^{6.55}$ was confirmed to be essential for 5-HT but not LSD potency at the receptor. Excitingly, the authors were also able to compare the calculated size of ligand binding pockets, and found that each ligand compared showed significant differences, with the $G_{\alpha q}$ bound state being significantly more open on the extracellular side in comparison with LSD. Most likely, this phenomenon is ligand specific, however the clarification of more ligand-bound $\mathrm{G}_{\alpha q}$ coupled structures are necessary to solidify the observation.

Indeed, further work on understanding the functional selectivity of the $5 \mathrm{HT}_{2 \mathrm{C}}$ receptor yielded similar interesting observations [126]. Here, Peng et al. solved the receptor structure in both an agonist (ergotamine) and an inverse agonist (ritanserin) bound state which allowed them to investigate the structural aspects of ligand promiscuity and selectivity in $5 \mathrm{HT}_{2}$ receptors. Similarly to $5 \mathrm{HT}_{2 \mathrm{~B}}$ and other biogenic amine receptors, $5 \mathrm{HT}_{2 \mathrm{C}}$ activation included a significant outward movement of the intracellular TM6, and a shift of the Trp ${ }^{6.48}$ P-I-F motif micro-switch. Excitingly, they identified the conserved residues $\operatorname{Trp}^{6.48}$ and Phe ${ }^{6.44}$ to be largely involved in G-protein coupling, without any influence on arrestin activity. The structure also suggests two residues mentioned with the $5 \mathrm{HT}_{2 \mathrm{~A}}$ inactive structure $\left(\mathrm{Gly}^{5.42}\right.$ and $\left.\mathrm{Val}^{7.39}\right)$ to mediate ritanserin's selectivity for the $5 \mathrm{HT}_{2}$ receptors.

Apart from key residues responsible for ligand-receptor specificity, information concerning critical switches and residues in 5-HT receptors mediating subsequent signal bias are crucial. Structural data from the Roth lab suggests that the preferential $\beta$-arrestin2 recruitment of ergoline compounds such as LSD on the $5 \mathrm{HT}_{2 \mathrm{~B}}$ receptor is both a result of a slow disassociation of the compound due to recruitment by the second extracellular loop (ECL2) and a ligand recognition motif in the extended binding pocket, particularly with the seventh transmembrane residue Leu ${ }^{7.35}$ [127]. Similar data for the importance of this residue as a factor in signal bias has been indicated for other aminergic receptors such as the $\kappa$-opioid receptor and the $\beta_{2}$-adrenergic receptor $[133,134]$. Likewise, the phenomenon of the lid-like ECL2 interactions increasing ligand residence time resulting in augmented $\beta$-arrestin recruitment has been suggested in other aminergic receptors [125, 135]. Intriguingly, residue contacts on the orthosteric binding pocket of $5 \mathrm{HT}_{2 \mathrm{~B}}$ failed to show any bias towards $\mathrm{G} \alpha_{\mathrm{q}}$ signaling or $\beta$-arrestin2 recruitment, instead the key residues $\left(\mathrm{Thr}^{3.37}, \mathrm{Ala}^{5.46}\right)$ contributed uniformly towards their recruitment. These observations imply that coordinated, receptor wide changes contribute to the degree of $\beta$-arrestin2 recruitment with specific residues contributing on the preference of G-protein or $\beta$-arrestin2 recruitment [136]. For example, in the LSD$5 \mathrm{HT}_{2 \mathrm{~A}}$ structure, mutation of Ser ${ }^{5.46}$ did not change binding affinity, but did alter disassociation rate of LSD, highlighting the potential role of this residue in $\beta$-arrestin recruitment [132]. In the case of the $5 \mathrm{HT}_{2 \mathrm{~B}}$ receptor, contact with TM7 $\mathrm{Leu}^{7.35}$ appears to be crucial for triggering biased signaling. Lastly, the availability of the $5 \mathrm{HT}_{2 \mathrm{~B}}$ structure is also important as it should allow better attempts at avoiding its activation. It is abundantly expressed in heart valves and can thus cause serious side effects for medications that are meant to target 5-HT receptors in brain cell populations [137].

Further meta-analysis of several aminergic GPCRs solved both in the active and inactive state divided the common activation pathway of these receptors into four layers of 34 conserved residue pairs [138] and break the transmembrane helical changes down to three main steps: (1) elimination of TM3-TM6 contacts (2) TM3-TM7 contact formation and (3) repacking of TM5 and 6. The authors then went on to exploit these details and successfully designed several previously unknown constitutively active and inactive mutants for the $5 \mathrm{HT}_{1 \mathrm{~B}}$ and $5 \mathrm{HT}_{7}$ receptors. (For detailed reviews on structural insights of serotonergic receptors, refer to refs. [136, 139]).

The identification of these key residue sites for ligand interactions that maximize ligand: receptor specificity, stabilize different receptor states and define specific signaling outcomes are crucial for the future design of selective, tailored ligands, especially as increased computational power and access to in silico screening tools provide faster routes of ligand discovery [76].

\section{Allosteric modulators}

The majority of ligands mentioned above exert their actions largely through interactions in the orthosteric binding site of their respective targets, however the potential of allosteric modulators should not be underrepresented. As their names suggest, allosteric modulators can be defined as ligands which bind to an alternative, distinct site separate from the endogenous agonist and thereby potentiate or inhibit the orthosteric bound agonist response (Fig. 2) [140, 141]. Thus, allosteric and orthosteric binding are not mutually exclusive but rather influence each other [142]. Positive allosteric modulators (PAMs) are substances which decrease the disassociation rate of an agonist from the orthosteric site, whereas NAMs increase the disassociation rate. Thus, pharmacologically speaking PAMs increase the apparent affinity of the endogenous agonist for the receptor, while NAMs decrease the ligand affinity. Neutral modulators which compete for the allosteric binding site with PAMs and NAMs without influence over agonist off-rate 
and affinity have also been described [141, 142]. As these effects are dependent on the orthosteric ligand it also means the observed effects are specific for each pair analyzed, thus especially in the context of modulating an endogenous process, modulators should be interpreted in the presence of the endogenous agonist whenever possible [143].

Allosteric modulators present several pharmacological advantages compared to traditional ligands, especially in the context of neuropharmacological challenges such as depression treatment. With regard to drug specificity, allosteric binding sites are less conserved between receptors compared to their orthosteric counterparts and thus, allosteric modulators may offer greater accuracy with regards to receptor selectivity [141]. Furthermore, a common issue with chronic administration of receptor agonists is receptor desensitization, however PAMs only modulate the effects of an endogenous agonist when it is present and bound to the receptor [141]. Instead of a continuous stimulation of an exogenous agonist which would result in a change in the temporal signaling profile of the target receptor, PAMs may provide therapeutic alternatives with greater long-term reliability.

The potential for allosteric modulators in treating MDD is considerable and can be foreshadowed by some existing medications. For example, the family of benzodiazepines which have been prescribed for anxiety disorders since the 1960s, act as allosteric modulators on the $\mathrm{GABA}_{\mathrm{A}}$ receptor [144]. Furthermore, ketamine, the previously discussed breakthrough antidepressant treatment, is interestingly an allosteric antagonist of the NDMA receptor, occupying the same allosteric binding site as MK-801 (trade name dizocilpine) [145].

Initial efforts on uncovering the mechanism of glutamate in anxiolytic and antidepressant drugs indicated that mGluR $_{5}$ antagonists display antidepressant properties, partly through an inhibitory crosstalk with NMDA receptors [146, 147]. Although the link between this receptor and MDD remains to be fully understood, there is evidence that the antidepressant action of mGluR $_{5}$ antagonists is mediated by parvalbumin-positive GABAergic cortical interneurons [148]. There are several mGluR $_{5}$ NAMs that have been developed and showed promise in preclinical settings but with rather limited clinical outcomes. AZD2066, an mGluR $_{5}$ NAM underwent an RCT (NCT01145755), but it was prematurely stopped. Basimglurant, also an mGluR $_{5}$ NAM failed to show significant improvement in the primary outcome measures but revealed efficacy among secondary outcome endpoints in an MDD focused RCT [149]. GRN529, another NAM acting on mGluR $_{5}$ was shown to improve depressive behaviors in vivo in rodents, but remains to be examined in human clinical trials [150].

Antidepressant actions of compounds acting on other mGluR's, more specifically in groups II and III, have also been elucidated; the mGluR $_{2 / 3}$ NAM Ro449153 exhibited promise in preclinical settings and another mGluR $_{2 / 3}$ NAM BCI-632 displayed antidepressant effects in rodent models and has been evaluated by an RCT for MDD treatment [151]. JNJ-40411813, an mGluR 2 PAM, was evaluated as an adjuvant treatment in depression and anxiety, with no significant primary outcome efficacy scores versus placebo treatment however it showed efficacy at secondary outcome measures of both depression and anxiety [152]. THIIC, a mGluR $_{2}$ PAM, shows significant antidepressant effects in rodent models of depression [153]. Recent work employing transgenic animals and optogenetics indicate that selective inhibition of $\mathrm{mGluR}_{2 / 3}$ in the PFC induces antidepressant effects which was also observed with NAMs for both receptors although with different modes of action; mGluR $_{2}$ via thalamocortical presynaptic glutamate release enhancement and $\mathrm{mGluR}_{3}$ via mediating postsynaptic plasticity [154].

\section{Polypharmacology}

Instead of designing a highly specific and tailored ligand for one receptor (i.e. a magic bullet), targeting one cell population and pathway, approaches have been made to pursue several targets with one compound (Fig. 2) [155]. As depression itself exists as a multifaceted disease with a multidimensional clinical profile likely as a result of numerous molecular alterations in the patient, it is unlikely that effective treatment can be achieved by pharmacologically focusing on one target [43, 112, 155]. Therefore, modulating two or more targets is probably necessary for a positive clinical outcome, which can be achieved either by combining multiple drugs (polypharmacy) or designing a drug with multiple targets (polypharmacology). Most classical drugs used to treat depression such as tricyclics display a substantial effect outside of their intended target (biogenic amine transporters) and as mentioned earlier, several already existing antidepressants such as agomelatine, vilazodone, and vortioxetine similarly target several receptors at once [43, 79, 155]. Lastly, the effect of several 'single action' SSRIs have been shown to be dependent or modulated by several 5-HT receptors [156-158]. Thus, it is clear that the large majority of existing medications already target a plethora of different cellular components. (For a comprehensive review on polypharmacy and major depression treatment see ref. [112]).

Other avenues of multitarget compounds could similarly extend to acting on both a receptor and a non-receptor such as an enzyme, for example monamine oxidase (MAO). MAO inhibitors (incl tranycypromine) are used in atypical forms of depression, and compounds such as 8-(3Chlorostyryl)caffeine have been found which both acts as an adenosine $\mathrm{A}_{2 \mathrm{~A}}$ receptor antagonist and a MAO-B 
inhibitor [159]. Owing to the availability of the crystal structure of both proteins, large scale virtual docking enabled the discovery of several specific compounds which could act on both targets [160]. Similar approaches have been used to identify novel MAO inhibitors which also act on several other GPCRs such as DA and histamine receptors $[161,162]$. As the structures of the $5 \mathrm{HT}_{2 \mathrm{~A}, 2 \mathrm{~B}, 2 \mathrm{C}}$ and $5 \mathrm{HT}_{1 \mathrm{~B}}$ receptors have already been solved, they present an opportunity for discovering dual acting compounds on relevant depression targets. Additionally, computational methods have been successfully exploited to automate the design of ligands with polypharmacological, CNS penetrant profiles [163].

\section{Receptor dimers}

The idea of higher order receptor structures, i.e. dimers, trimers, and oligomers, adds another dimension of GPCR pharmacology. Since their hypothesis in the 1980s, numerous studies have now shown that receptor signaling is not only largely influenced by the conformational changes that take place following direct ligand contact, but that these conformational changes can also be influenced by allosteric interactions with other receptors on the plasma membrane [164-166]. Receptor dimerization on the cell-surface membrane is obligatory to class $\mathrm{C}$ members, making them extremely peculiar in terms of pharmacological function and energetics. One of the best documented cases of a functional heterodimer is the class C GPCR $\mathrm{GABA}_{\mathrm{B}}$ complex, wherein one subunit (receptor) binds the ligand, and the other exerts an intracellular response via G-protein recruitment (Fig. 2) [167]. Outside of Class C dimers, many efforts to discover other dimers have shown promise but the physiological reality of these must be carefully interpreted, as overexpression models and immunoprecipitation methods may highlight mere transient interactions which are not fully relevant or yet understood.

The allosteric influences between receptors can switch the coupling profile of a GPCR and influence maturation and internalization rates [168]. $5 \mathrm{HT}_{1 \mathrm{~A}}$ and $5 \mathrm{HT}_{7}$ dimers have also been suggested in hippocampal neurons with effects on $5 \mathrm{HT}_{1 \mathrm{~A}}$ GIRK activation [169]. The different receptor states (monomers, dimers, oligomers) also display differential affinities for ligands. Separate from altered ligand affinity, heterodimers have been proposed to facilitate cross-talk between neurotransmitter GPCRs (e.g. $\mathrm{D}_{2}$ $\mathrm{A}_{2 \mathrm{~A}}$ heterodimers) [170], neurotransmitter and neuropeptide GPCRs (e.g. 5 $\mathrm{HT}_{1 \mathrm{~A}}$-GalR heterodimers) [171], neurotransmitter receptor-neurotrophic factor receptors (e.g. $5 \mathrm{HT}_{1 \mathrm{~A}}$-FGFR1 heteromers) [172, 173] and GPCRs and ionotropic receptors (e.g. $\mathrm{D}_{1}$-NMDA heteromers) [174]. However, the challenge of evaluating the therapeutic potential of these receptor associations remains difficult, especially in vivo. (for an in depth-review on GPCR heteromerization criteria see [175]).

These associations can be exploited to enhance therapeutic potential by targeting the unique receptor complex. Heteromer targeting drugs may also offer increased precision as they could leverage the receptor species expression heterogeneity amongst different cell types. Two compounds joined by a linker which can recognize and bind the two receptors in a protomer (known as bivalent ligands) have been developed for a different receptor groups and have been shown to be successful in applications such as nociception reduction [176, 177]. Bivalent ligands targeting depression targets are still lacking, however. A large challenge here is that these linked compounds are bulky and are thus difficult to be made blood-brain barrier (BBB) penetrant [178]. Although the literature is scarce concerning receptor dimers in depression, $\mathrm{D}_{1}-\mathrm{D}_{2}$ dimers were shown to be elevated in the striatum of MDD patients, and interference of these dimers in a rats significantly reduced immobility time in the FST [179]. Further potential targets are outlined in [180].

\section{Antibody-based approaches to target GPCRs}

A field undergoing significant growth and development in the last two decades is immunotherapy and biologics based treatments. Immune recruitment approaches in cancer have been revolutionary, reflected by the Nobel Prize in Physiology or Medicine in 2018 being awarded for the development of immune checkpoint therapies. Autoimmune diseases such as multiple sclerosis have seen positive outcomes with antibody-based therapies such as rituximab and inflammatory bowel disease and rheumatoid conditions are currently often treated with antiinflammatory antibodies.

Traditionally, antibody generation against GPCRs has been notoriously difficult, largely due the difficulty of extracting and preparing them in their native state based on their lipophilic environment. Furthemore, in vivo, only the extracellular portion of the receptor in its native form is available for the antibody to recognize. However, the largest degrees of variance between receptors are seen in the loops, $\mathrm{N}$ and $\mathrm{C}$ termini, which should theoretically provide some relief over antibody specificity. As most GPCRs display the $\mathrm{N}$ terminus and extracellular loops (ECLs) on the antibody accessible extracellular side, N-terminally or ECL targeted antibodies are appealing for certain therapeutic applications. Interestingly, this phenomenon can be observed in nature as antibodies directed against GPCRs have long been described in the context of Graves' disease [181]. Here, autoantibodies are generated against the thyroid-stimulating hormone receptor and act as an agonist on the receptor stimulating the proliferation of the thyroid gland. 
Antibody-based therapeutics may be useful for GPCR targeting, especially for the aminergic receptors, due to their extreme target specificity and potential ability to act as a ligand (Fig. 2). Accordingly, antibody screens for specific antibodies with agonist properties have been described for targets such as GLP-1 for purposes of diabetes treatment $[182,183]$ and more recently, the chemokine receptor CCR1 [184].

Even if one manages to generate potent GPCR targeting antibodies, the issue of BBB permeability is immediate, especially in the context of MDD treatment. Although the mechanism of uptake remains unknown, autoimmune diseases such as NMDA receptor encephalitis are caused by autoantibodies against a neuronal receptor which are able to cross the BBB [185]. Another similarity in nature is Ophelia's syndrome, a subset of Hodgkin's disease which develop autoantibodies against mGluR $_{5}$ [186]. Additionally, chronic stress, anxiety, and depression have all been linked to a more vulnerable and leaky BBB which would be useful from the perspective of antibody therapy against relevant neurological targets [187, 188]. Similarly, antibody engineering techniques such as the development of bispecific antibodies targeting the transferrin receptors have been extensively used to facilitate a greater degree of BBB penetrance [189-191]. Together, the present antibody engineering techniques and disease phenomenon described in nature do not deny the feasibility of BBB penetrant GPCR targeting antibodies.

An extension of modern antibody therapies geared against GPCRs can be observed in the calcitonin receptor like receptor (CLR) treatment of migraines [192]. A fully human antibody named Erenumab was approved by the FDA and EMA since 2018 for pain management in migraines. It acts as an antagonist of the receptor with a reported $\mathrm{IC}_{50}$ of $2.3 \mathrm{nM}$ in cell based functional assays [193]. Erenumab is peculiar as it is bispecific, a fusion of two antibodies for the $\mathrm{N}$ terminus of CLR and the Nterminal portion of the receptor activity-modifying protein (RAMP)-1. RAMPs are single pass membrane proteins, belonging to the group of adaptor proteins, which themselves are important for the ligand selectivity, trafficking, signaling, and degradation of GPCRs. Although Erenumab is not BBB permeable, it highlights the success and possibility of developing antibody therapies targeting GPCRs, which can be engineered for BBB permeability in MDD treatment applications.

\section{Intracellular GPCR targeting}

The classical model in which GPCR signaling occurs exclusively on the surface plasma membrane has also been expanded on as continued receptor signaling within several intracellular compartments has been elucidated [194]. More specifically, GPCR signaling has been shown to occur on the nuclear, mitochondrial, endosomal, and Golgi membranes in addition to the surface plasma membrane [195-198]. Some receptors such as those localized to early endosomes appear to maintain their intact signaling configuration from the agonist they bound on the surface membrane and then repurpose this signaling once they are internalized. Others, such as cannabinoid 1 and melatonin type 1 receptors on the mitochondrial membrane seem to serve an entirely unique, intracellular purpose [196, 199]. Accordingly, these cascades while largely unexplored hold potential for treatments towards a variety of disease (Fig. 2). One such example is the substance $\mathrm{P}$ bound neurokinin 1 receptor which continues to elicit a signaling cascade resulting in pain transmission once internalized in endosomes. Jensen et al. showed that targeting of this endosomal signaling complex using membrane-anchored antagonist conjugates is able to constrain the pain transmission more efficiently than "standard" surface plasma membrane receptor targeting antagonists [197]. Another approach interfering with the same receptor was successfully accomplished using $\mathrm{pH}$ sensitive nanoparticles containing an antagonist which were endocytosed into the same compartments as the active neurokinin 1 receptor, releasing the antagonist [200]. Additionally, an appealing receptor in dopaminergic transmission and addiction research, the trace amine associated receptor 1 was also recently shown to couple to different G-proteins depending on the intracellular compartment, thus eliciting different signaling cascades when bound to the psychostimulant amphetamine [201]. While so far only a handful of receptors have been shown to be capable of mediating signal transduction pathways from an intracellular compartment, this emerging field garners great potential for more efficient and specific receptor targeting. Furthermore, research towards intracellular signaling in other pathological states such as MDD where normal cell-surface signaling may be crucial for normal function, but intracellular states may provide better treatment targets.

\section{Role of adaptor proteins in GPCR-mediated actions with an emphasis on Homer and p11}

Adaptor proteins link protein-binding partners together and facilitate the formation of signaling complexes. Many adaptor proteins, including RGS and AGS proteins, regulate GPCR signaling, but here we focus on GPCR-interacting proteins. Such proteins are important for the ligand selectivity, trafficking, signaling, and degradation of GPCRs [202]. Studies on how adaptor proteins modulate GPCRs have led to successful drug development. Receptor activitymodifying proteins (RAMPs) are single pass membrane adaptor proteins which have turned out to be critical for GPCR functions. RAMPs were initially identified by their 
ability to bind to and determine the pharmacology of the calcitonin receptor-like receptor (CLR). The interaction of RAMPs with GPCRs is of considerable importance for drug discovery. CLR/RAMP1, or CGRP receptor, antagonists have been developed for the treatment of migraine headache. As mentioned above, specific antisera has been developed, but there are also small molecules antagonizing the CGRP receptor in the clinics [203].

Two GPCR-interacting proteins that have implicated in MDD are homer and p11. Homer is an immediate early gene with a PDZ domain which bind to the cytoplasmic tail of mGluR5, and regulate the cell-surface localization and signaling of this GPCR [204]. It has indeed been shown that various antidepressants increase homer1 in PFC [205]. Accordingly, viral overexpression of homer1 in the PFC causes antidepressant effects in rodents [205]. Moreover, it was subsequently shown that intravenous injection of a cellmembrane-permeable TAT-Homer1 construct causes antidepressant effects [206]. In this study, it was also shown that Homer1-mediated enhancement of mGlu5 signaling promotes antidepressant effects by potentiating AMPA receptor activation [206]. Conversely, siRNA-mediated knockdown of homer1 in mPFC enhanced depressive-like behavior [205]. Interestingly, a linkage between Homer and MDD has been described in a genome-wide association study, indicating a possible role for Homer in the pathophysiology of depression [207].

An adaptor protein that is implicated in 5-HT and glutamate signaling is P11 (S100A10, annexin II light chain, calpactin I light chain). P11 is a multifunctional protein of the S100 protein family which forms a heterotetrameric scaffold with AnnexinA2 particularly at cell membranes. P11, alone or together with AnnexinA2, interacts with several ion channels and receptors and regulates their cellular localization and function [208]. p11 levels are downregulated in the cingulate cortex and the ventral striatum from MDD patients and suicide victims [209-211]. Constitutive p11 KO mice show a depression-like behavioral phenotype in several wellestablished models that measure behavioral despair (e.g., forced swim and tail suspension tests) or anhedonia (e.g., sucrose preference test) [211]. Site-specific conditional knockout of p11 in NAc cholinergic interneurons produces a depression-like behavioral-phenotype [212].

As shown in Fig. 3, p11 is co-localized with $5-\mathrm{HT}_{1 \mathrm{~B}}$ and/or $5-\mathrm{HT}_{4}$ in many cell types of the cerebral cortex, hippocampus, and NAc [211, 213]. The third intracellular loop of $5-\mathrm{HT}_{1 \mathrm{~B}}, 5-\mathrm{HT}_{1 \mathrm{D}}$, and $5-\mathrm{HT}_{4}$ interact with $\mathrm{p} 11$ $[211,214]$. p11 increases the surface expression and signaling via of $5-\mathrm{HT}_{1 \mathrm{~B}}$ and $5-\mathrm{HT}_{4}$ and agonists at $5-\mathrm{HT}_{1 \mathrm{~B}}$ or $5-\mathrm{HT}_{4}$ exert antidepressant action which are dependent on p11 [211, 214]. More recently, it has been shown that stimulation of a 5-HT1B/p11 pathway cholecystokinin (CCK) GABAergic interneurons of the dentate gyrus region of hippocampus is important for initiating the therapeutic response to fluoxetine [215]. In fact, several antidepressant treatments, including fluoxetine, imipramine, tranylcypromine, and electroconvulsive therapy have been shown to up-regulate p11 levels in frontal cortex and hippocampus from rodents [211]. Accordingly, p11 KO mice show reduced responses to antidepressants in various tests for antidepressant efficacy [211]. Likewise, selective deletion of $\mathrm{p} 11$ in corticostriatal layer $5 \mathrm{a}$ or hilar hippocampal interneurons blunts the antidepressant action of SSRIs [216-218].

Using the chronic unpredictable mild stress model of depression and lentiviral knockdown of hippocampal p11 suggested that p11 may also have a key role in the sustained antidepressant effect of ketamine [219]. A direct link between p11 and the glutamate system is that 111 binds directly to a Ser-Thr-Val sequence in the cytoplasmic tail of mGluR $_{5}$ and facilitates its accumulation at the plasma membrane [148]. p11 overexpression potentiates mGluR $_{5}$ agonistinduced calcium responses in cultured cells [148]. Knockout of $\mathrm{mGluR}_{5}$ or p11 specifically in forebrain glutamatergic cells in mice produces depression-like behaviors [148]. On the contrary, deletion of mGluR $_{5}$ or p11 in GABAergic neurons results in antidepressant-like behaviors [148].

It has also been shown show that SMARCA3, a chromatin-remodeling factor, is a target for the p11/annexin A2 heterotetrameric complex [220]. Formation of this complex increases its nuclear localization and the DNAbinding affinity of SMARCA3. SSRI-induced neurogenesis and behavioral responses are abolished by constitutive or mossy cell-specific knockout of SMARCA3 [218, 220]. Apart from annexin A2, it has been reported that p11's interaction with Ahnak exhibits crucial role in depressivelike behavior [221]. Particularly, p11/Ahnak complex increases the trafficking to the membrane of L-type voltagegated calcium channels [221].

\section{Circuitries involved in MDD and targeted via neuropeptide GPCRs}

Neuropeptides are short proteins ranging from 3 to around 40 amino acids and very often coexist with classical transmitters in the brain. They act via GPCRs to play a role particularly when the nerve cells are challenged by stress or injury. Thus, neuropeptide receptors are considered as attractive targets for pharmacological intervention of depression. We have in other places of this review indicated roles for GPCRs targeted by CRH, AVP, and endorphins in MDD. In this section, we focus our discussion on receptors of galanin, neuropeptide Y (NPY), and oxytocin.

Galanin is a 29/30 amino-acid neuropeptide with three G-protein coupled receptors termed as $\mathrm{GalR}_{1}, \mathrm{GalR}_{2}$, and 


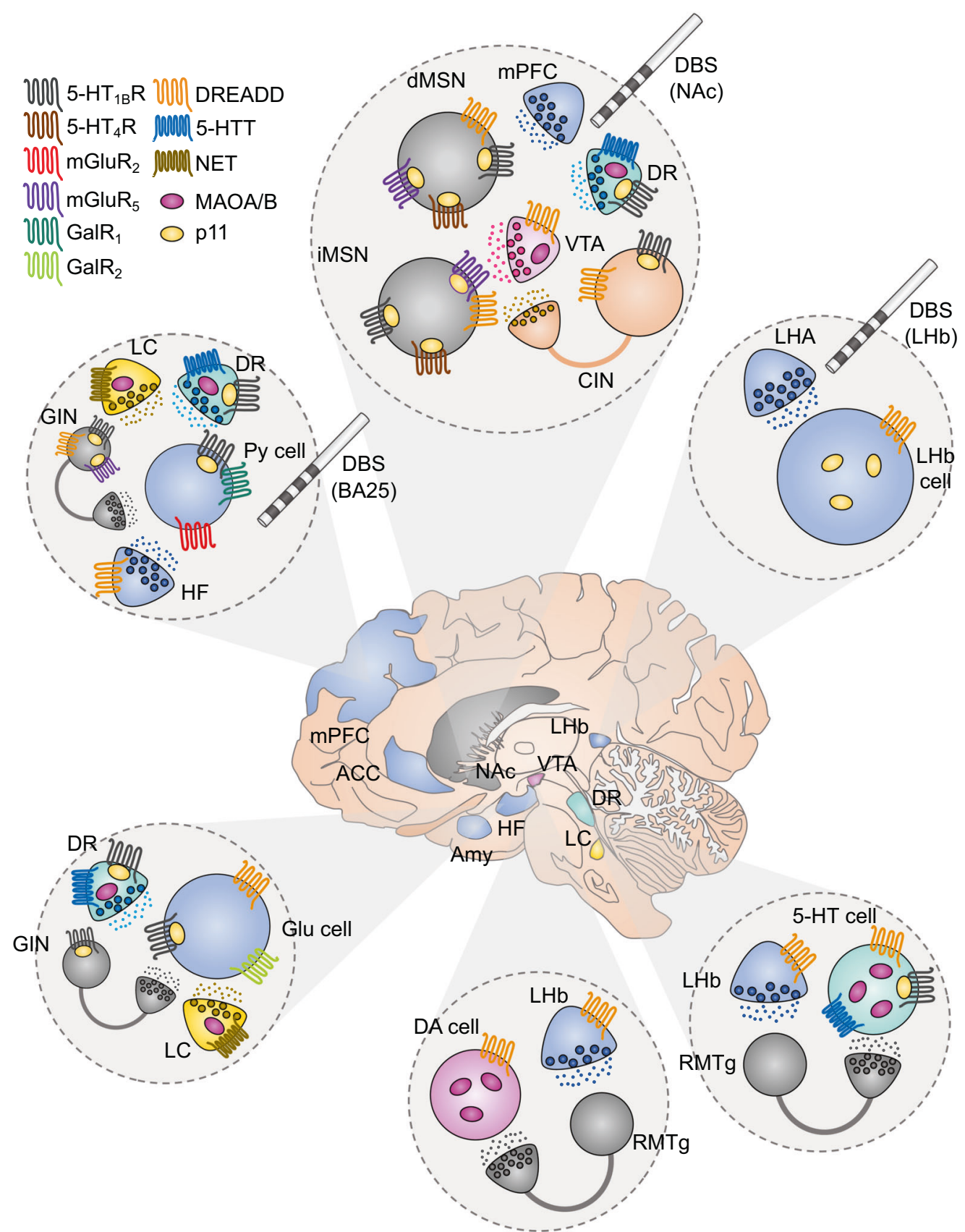

Fig. 3 Novel GPCR-based therapeutical strategies in brain regions involved in MDD. In the center, it is depicted the human brain together with different brain areas that are involved in the symptomatology of MDD. Each circle panel shows the neuronal types that have been found to affect depressive-like behavior together with the receptors that they express. GABA neurons/terminals: gray, glutamate neurons/terminals: blue, DA neurons/terminals: pink, 5-HT neurons/ terminals: cyan, NE neurons/terminals: yellow, cholinergic neurons/ terminals: orange. VTA ventral tegmental area, mPFC medial prefrontal cortex, LHA lateral hypothalamic area, NAc nucleus

$\mathrm{GalR}_{3}$ [222]. Many studies have demonstrated that galanin and its receptors are involved in the pathology of depression. Thus, the activation of $\mathrm{GalR}_{1}$ and $\mathrm{GalR}_{3}$ results in depression-like behaviors, whereas stimulation of $\mathrm{GalR}_{2}$ accumbens, DR dorsal raphe, LHb lateral habenula, RMTg rostromedial tegmentum, ACC anterior cingulate cortex, BA25 Brodmann area 25, HF hippocampal formation, Amy amygdala, dMSN direct medium spiny neuron, iMSN indirect medium spiny neuron, CIN cholinergic interneuron, GIN GABAergic interneuron, Py pyramidal, Glu glutamate, DA dopamine, 5-HT serotonin, 5-HTT serotonin transporter, NET norepinephrine transporter, MAOA/B monoamine oxidase A/B. DREADD designer receptors exclusively activated by designer drugs, DBS deep brain stimulation.

leads to antidepressant-like effects [223]. Accordingly, GalR $_{2}$-knockout mice show depression-like behaviors, while $\mathrm{GalR}_{2}$-overexpressing mice exhibit antidepressantlike behaviors [224, 225]. It has been reported that $\mathrm{GalR}_{1}$ 
mRNA is significantly and selectively upregulated in the vPAG of rats exposed to chronic mild stress (CMS) and GalR $_{1}$-siRNA knockdown of the upregulated GalR 1 reverses depression-like behaviors [226].

NPY exerts its responses via five receptor subtypes, termed $\mathrm{Y}_{1} \mathrm{R}, \mathrm{Y}_{2} \mathrm{R}, \mathrm{Y}_{4} \mathrm{R}, \mathrm{Y}_{5} \mathrm{R}$, and $\mathrm{Y}_{6} \mathrm{R}$ and has been implicated in anxiety and depression [227, 228]. Among them, $\mathrm{Y}_{1} \mathrm{R}$ mediates NPY-induced antidepressant activity in the olfactory bulbectomized rats (OBX) [229] as well as in the forced swim test in mice [230]. Meanwhile, $\mathrm{Y}_{5} \mathrm{R}$ antagonist has antidepressant-like effects in CMS [231] and FSL [232] rats.

Oxytocin is one of the most important neuroregulators mediating social behaviors and stress-related disorders and plays an antidepressant role in depression [233]. It has been demonstrated that oxytocin levels are inversely correlated with depressive symptoms [234]. Administration of oxytocin were shown to reduce immobility time of FST in mice [235] and reverse depressive-like behaviors and high plasma corticosterone level in postpartum depression rats [236], indicating that central oxytocin exerts antidepressive effects.

\section{Orphan GPCRs localized in circuitries involved in MDD}

Technological advances in transcriptional profiling of distinct cellular subpopulations, but also in situ detection of mRNA transcripts has revealed expression patterns of novel orphan brain-specific GPCRs (Fig. 4).

As we mentioned above, the activity of the NAc is crucial for the expression of both positive and negative emotions. There are several orphan GPCRs, such as GPR88, GPR101, GPR52, and GPR6, which display a robust striatal expression and have been associated to anxiety and/or depressive-like states [237]. GPR88 mRNA levels have been described to be altered after the treatment with antidepressants in both animal models and humans [238, 239]. GPR88 displays the highest amino-acid sequence homology to the amine-GPCR family and specifically with $5-\mathrm{HT}_{1 \mathrm{D}}$ receptor [240]. GPR88 is strikingly expressed in the corticostriatal contacts of both dMSNs and iMSNs with some enrichment to striosomes [241, 242]. GPR88 is coupled to $\mathrm{G} \alpha_{\mathrm{i}}$ and affects the MSN excitability through impeding the membrane trafficking of AMPAR [241]. Selective of GPR88 deletion in iMSNs is sufficient to reproduce the anxiolytic phenotype observed in the global GPR88 KO mice [243, 244]. There is evidence that GPR88 is expressed in the DRN and regulates 5-HT levels [245, 246]. Although, it has been shown that GPR8 8 mRNA levels are changed with antidepressant treatment [238, 239] further behavioral studies are needed to evaluate the effect of GPR88 on depression-like behavior. Whereas the endogenous ligand of the receptor remains elusive, several centrally active ligands towards GPR88 has been developed [247]. Another GPCR which has also been characterized by its striatal enrichment and its relationship to adrenergic receptors, is GPR101 [248]. It is a $\mathrm{G} \alpha_{\mathrm{s}}, \mathrm{G} \alpha_{\mathrm{q} / 11}$, and $\mathrm{G} \alpha_{12 / 13}$ coupled receptor and is enriched in the matrix compartment of the striatum [248, 249]. Mice lacking GPR101 display higher immobility time in the forced swim test [248]. GPR52, a $\mathrm{G} \alpha_{\mathrm{s}}$ coupled orphan GPCR, is localized uniquely in iMSNs of striatum and GPR52 KO mice demonstrate an anxietylike phenotype [237, 250]. The recently solved crystal structure of GPR52 is providing new insights for the development of novel pharmacological tools [250]. Future studies are required to examine the role of GPR52 in depression-like behaviors. However, since $\mathrm{G} \alpha_{\mathrm{i}}$ coupled $\mathrm{D}_{2}$ receptors in iMSNs exert antidepressant properties, it is not unlikely that GPR52 antagonists may be antidepressant. Recently, it has been shown that small molecule GPR52 agonists (BD442618, BD502657) can reduce ropinirole actions. Accordingly, future development of GPR52 antagonist might enhance D2 receptor agonist actions. modulate $\mathrm{D}_{2}$ receptors and GPR52 shares almost identical expression profile and G-protein coupling with the striatal enriched GPR6 [237, 251]. Lately, it has been reported that $\mathrm{N}$-arachidonoyl dopamine, $\mathrm{N}$-docosahexaenoyl dopamine, $\mathrm{N}$-oleoyl dopamine, and N-palmitoyl dopamine display inverse GPR6 agonist properties [252]. These are endogenously occurring compounds which may be enriched in striatum due to their close relationship to DA [252]. Even though there are no studies about GPR6 effects on anxiety or depression-like behaviors, this GPCR is another possible MDD drug target.

Since the discovery of LHb-RMTg aversion system, there have been attempts to selectively target the $\mathrm{LHb}$ to treat MDD [253]. In an effort to identify genetic tools to study LHb, GPR151 was discovered to have highly enriched expression within LHb [254-258]. Interestingly, the receptor shows extreme specificity to $\mathrm{LHb}-\mathrm{MHb}$ complex as it is barely detected in other brain areas or tissue types [254-257]. Its endogenous ligand still remains unknown, however its amino-acid sequence is related to galanin receptors [259]. Additionally, it has been reported that GPR151 may exhibit some acid sensing properties [260]. As the receptor is $G \alpha_{i}$ coupled and is specifically located in axons and presynaptic boutons, possible agonists may suppress habenular glutamate release [254, 257]. This is interesting in light of a recent study which has shown that intrahabenular administration of ketamine abolished burst firing of $\mathrm{LHb}$ neurons and induced an antidepressant-like effect mimicking the effects of the drug's systemic administration [86]. There is an anxiety-like behavioral phenotype in mice lacking the GPR151 expressing neurons [258]. However, its role in depression-like behaviors remains to be elucidated. Consequently, future development of GPR151 
Fig. 4 Orphan GPCRs expressed in brain regions involved in MDD. In the center, it is depicted the human brain together with different brain areas that are involved in the symptomatology of MDD. Each circle panel shows the neuronal types that have been found to affect depressive-like behavior together with the receptors that they express. GABA neurons/ terminals: gray, glutamate neurons/terminals: blue, DA neurons/terminals: pink, 5-HT neurons/terminals: cyan, $\mathrm{NE}$ neurons/terminals: yellow, cholinergic neurons/terminals: orange. VTA ventral tegmental area, mPFC medial prefrontal cortex, LHA lateral hypothalamic area, NAc nucleus accumbens, DR dorsal raphe, LHb lateral habenula, RMTg rostromedial tegmentum, ACC anterior cingulate cortex, $\mathrm{HF}$ hippocampal formation, Amy amygdala, dMSN direct medium spiny neuron, iMSN indirect medium spiny neuron, CIN cholinergic interneuron, GIN GABAergic interneuron, Py pyramidal, Glu glutamate, DA dopamine, 5-HT serotonin.

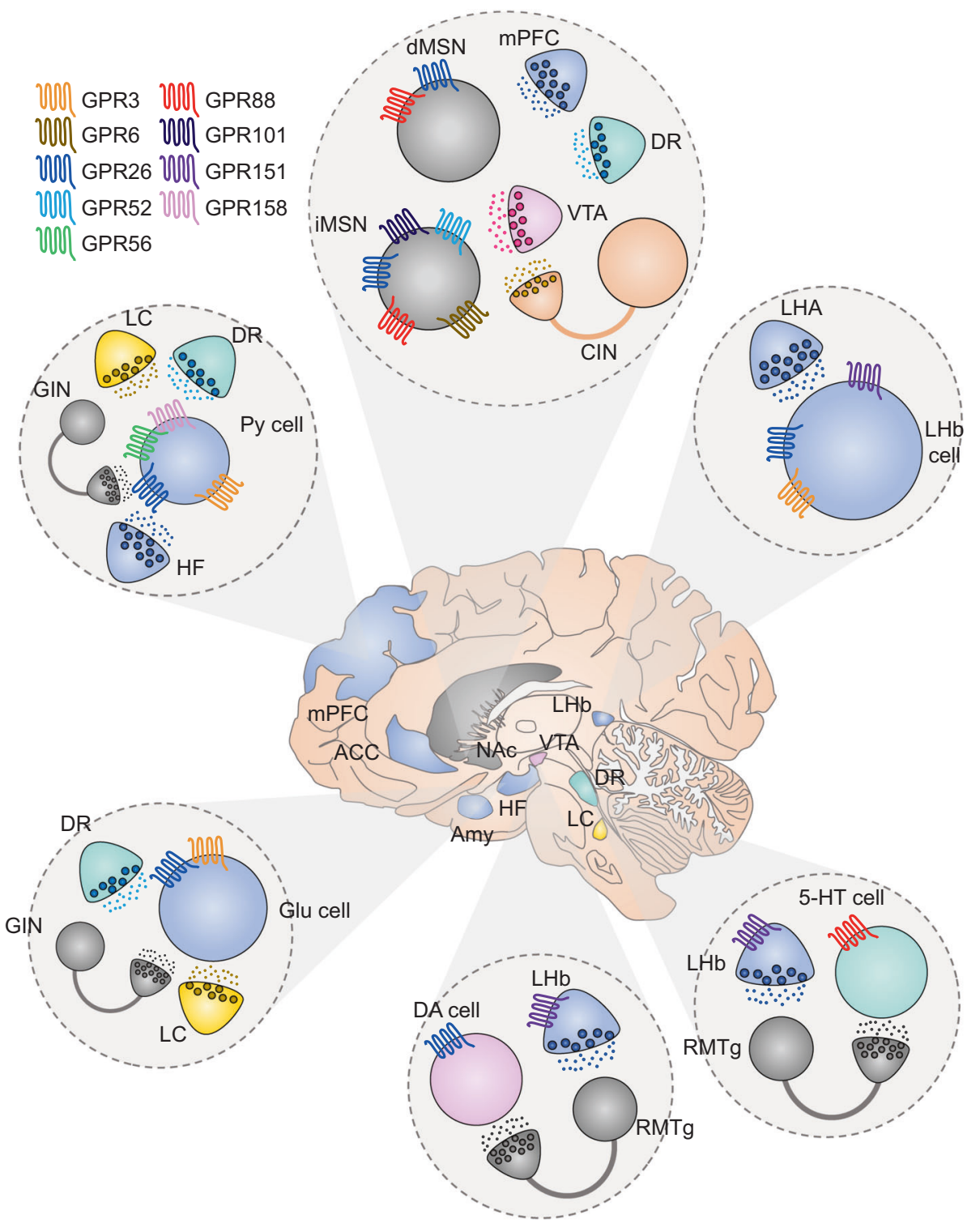

agonists would allow us to pharmacologically mimic LHb DBS and offer a fast and efficient drug induced alleviation of depressive symptoms.

There are some orphan GPCRs which are highly expressed in the PFC and that have been associated with anxietyand depression-like traits, such as GPR158, GPR56, GPR3, and GPR26. GPR158 gained attention through its remarkable upregulation in PFC in a stress-induced depression animal model but also in human patients diagnosed with MDD [261]. In spite of its presence in PFC, striatum and hippocampus, the aforementioned effect was observed solely in PFC glutamatergic cells of layer 2/3 [261]. In accordance, GPR 158 is the most abundantly expressed GPCR in the PFC, making it a potential key regulator of PFC activity [261]. The receptor's G-protein interaction properties have not been well clarified, however, there is evidence that it may be associated with RGS7 and Go $\alpha_{i}$ signaling [261-263]. GPR158's ability to suppress cAMP synthesis may decrease the activity of superficial cortical neurons and thereby induce depressive behavior [261, 263]. It is indeed possible to induce a depression-like phenotype in mice via viral-induced overexpression of GPR158 in the PFC [261]. Another GPCR with altered PFC expression levels following unpredictable chronic stress is GPR56 [264]. However, unlike GPR158, deletion of GPR56 is considered to aggravate depressive-like symptoms [264].

Two brain-specific $\mathrm{G} \alpha_{\mathrm{s}}$ coupled orphan receptors that have recently been associated with anxiety- and depressionlike behaviors, are GPR3 and GPR26 [265-267]. Both GPR3 and GPR26 KO mice were shown to spend less time in the open arms of the elevated plus maze test and displayed a higher immobility time in the forced swim test [265, 267]. Regarding their brain distribution, both receptors have been localized to PFC, striatum, hippocampus 
and habenular complex [265, 268-271]. Remarkably, GPR26 shows notable enrichment in DA cells of VTA. GPR3 is listed in the orphan family, but presents high sequence homology with lipid binding GPCRs such as lysophospholipid and cannabinoid receptors [272, 273]. In accordance, there is some evidence that sphingosine 1 phosphate is its endogenous ligand [274].

\section{Chemogenetic approaches to counteract depression}

Optogenetics pioneered a new era in studying functional neuroanatomical circuitries [275]. Optogenetics has been used to describe the role of different brain areas in controlling mood and depressive-like behavior. Another technique that includes the manipulation of neuronal activity with genetic tools, is chemogenetics [276-279]. The major difference between opto- and chemogenetics is that the first is using light sensitive ion channels to manipulate neuronal activity while the latter is exploiting engineered GPCRs which are stimulated selectively by specific exogenous ligands [280]. From a temporal perspective, ion channels cause rapid changes in membrane potential $(<1 \mathrm{~ms})$ while GPCRs initiate slower responses with longer duration (seconds-minutes) [281]. Consequently, optogenetics mimics fast neurotransmission whereas chemogenetics resembles slow neurotransmission. GPCRs used for chemogenetics are known as Designer Receptors Exclusively Activated by Designer Drugs (DREADDs). The first DREADDs were synthetic variants of muscarinic acetylcholine receptors coupled to $\mathrm{G} \alpha_{\mathrm{i} / \mathrm{o}}, \mathrm{G} \alpha_{\mathrm{q} / 11}$, or $\mathrm{G} \alpha_{\mathrm{s}}$ proteins according to the desired functional neuronal impact. The most commonly used ligand for DREADDs is clozapineN-oxide, which is usually administered systemically [276, 282]. Chemogenetic tools have been used to study the impact of different neuronal circuitries in regulating anxiety- and depressive-like phenotypes [276, 282]. Specifically, chemogenetic tools have been used to alter behavior in anxiety- and depression-related tests by manipulating the activity of VTA, NAc, mPFC, HF, LHb, and DRN. Chemogenetic activation of VTA abolished the anxiety and the increased immobility in FST in a genetic model of depression [283]. Suppression of NAc dMSN activity through inhibitory DREADDs causes susceptibility to social defeat in mice [49]. Chemogenetic blockade of mPFC GABAergic interneuron activity augmented learnedhelplessness behavior [284]. Chemogenetic targeting of ventral HF to mPFC projecting system reduces immobility in the FST [285]. Chemogenetic inhibition of LHb complex reduced immobility time in FST [286]. At the same time, suppressing LHb neuronal activity through DREADDs rescues the stress-induced social avoidance in SSRI- resistant 5-HT deficient mice [287]. Chemogenetic activation of 5-HT cells in the DRN produces a dichotomous effect upon anxiety and depression. DREADD-induced excitation of DRN boosts anxiety but decreases depressionlike behavior in mice [288].

In conclusion, chemogenetic approach in MDD animal models shows promising results for alleviating depressive-like mood. It was recently reported a successful effort to apply chemogenetics upon nonhuman primates, pushing the technology one step closer to human applications [289]. Since, gene therapy has been already used in clinical trials for PD and other disorders [290], chemogenetic strategies may be potential future treatments that will substitute DBS to specifically activate cell populations in critical brain circuitries.

\section{Conclusion}

Over the past years several promising attempts have been made to treat MDD with receptor-based approaches. Treatment with the NMDA receptor antagonist, ketamine, is a breakthrough in the field. Rapid scientific advances in brain neuropharmacology allow the development of additional innovative approaches to treat MDD. Particularly, structural and molecular biology advances of GPCRs illuminate the possibility of pathway specific multitarget pharmacological strategies that may boost efficacy of existing drug treatments. Simultaneously, the ever-expanding knowledge of orphan GPCR function provides an opportunity for the development of first-inclass antidepressant drugs characterized by higher regional specificity and efficacy.

Acknowledgements We would like to acknowledge Drs Makaía M. Papasergi-Scott and Georgios Skiniotis for providing the illustration of the GABAB complex before the structure was published.

\section{Compliance with ethical standards}

Conflict of interest The authors declare no competing interests.

Publisher's note Springer Nature remains neutral with regard to jurisdictional claims in published maps and institutional affiliations.

Open Access This article is licensed under a Creative Commons Attribution 4.0 International License, which permits use, sharing, adaptation, distribution and reproduction in any medium or format, as long as you give appropriate credit to the original author(s) and the source, provide a link to the Creative Commons license, and indicate if changes were made. The images or other third party material in this article are included in the article's Creative Commons license, unless indicated otherwise in a credit line to the material. If material is not included in the article's Creative Commons license and your intended use is not permitted by statutory regulation or exceeds the permitted use, you will need to obtain permission directly from the copyright holder. To view a copy of this license, visit http://creativecommons. org/licenses/by/4.0/. 


\section{References}

1. Malhi GS, Mann JJ. Depression. Lancet. 2018;392:2299-312.

2. Krishnan V, Nestler EJ. The molecular neurobiology of depression. Nature. 2008;455:894-902.

3. Schmaal L, Veltman DJ, Van Erp TGM, Smann PG, Frodl T, Jahanshad N, et al. Subcortical brain alterations in major depressive disorder: findings from the ENIGMA Major Depressive Disorder working group. Mol Psychiatry. 2016;21:806-12.

4. Belleau EL, Treadway MT, Pizzagalli DA. The impact of stress and major depressive disorder on hippocampal and medial prefrontal cortex morphology. Biol Psychiatry. 2019;85:443-53.

5. MacQueen G, Frodl T. The hippocampus in major depression: Evidence for the convergence of the bench and bedside in psychiatric research. Mol Psychiatry. 2011;16:252-64.

6. McEwen BS, Bowles NP, Gray JD, Hill MN, Hunter RG, Karatsoreos IN, et al. Mechanisms of stress in the brain. Nat Neurosci. 2015;18:1353-63.

7. Block TS, Kushner H, Kalin N, Nelson C, Belanoff J, Schatzberg A. Combined analysis of mifepristone for psychotic depression: plasma levels associated with clinical response. Biol Psychiatry. 2018;84:46-54.

8. Binneman B, Feltner D, Kolluri S, Shi Y, Qiu R, Stiger T. A 6-week randomized, placebo-controlled trial of CP-316,311 (a selective CRH1 antagonist) in the treatment of major depression. Am J Psychiatry. 2008;165:617-20.

9. Katz DA, Locke C, Greco N, Liu W, Tracy KA. Hypothalamicpituitary-adrenal axis and depression symptom effects of an arginine vasopressin type 1B receptor antagonist in a one-week randomized Phase 1b trial. Brain Behav. 2017;7:e00628.

10. Godlewska BR, Harmer CJ. Cognitive neuropsychological theory of antidepressant action: a modern-day approach to depression and its treatment. Psychopharmacology. 2020. https:// doi.org/10.1007/s00213-019-05448-0.

11. Levkovitz Y, Harel EV, Roth Y, Braw Y, Most D, Katz LN, et al. Deep transcranial magnetic stimulation over the prefrontal cortex: evaluation of antidepressant and cognitive effects in depressive patients. Brain Stimul. 2009;2:188-200.

12. Mayberg HS, Lozano AM, Voon V, McNeely HE, Seminowicz D, Hamani C, et al. Deep brain stimulation for treatment-resistant depression. Neuron. 2005;45:651-60.

13. Rudebeck PH, Rich EL, Mayberg HS. From bed to bench side: reverse translation to optimize neuromodulation for mood disorders. Proc Natl Acad Sci USA. 2019;116:26288-96.

14. Francis TC, Lobo MK. Emerging role for nucleus accumbens medium spiny neuron subtypes in depression. Biol Psychiatry. 2017;81:645-53.

15. Drevets WC, Videen TO, Price JL, Preskorn SH, Carmichael ST, Raichle ME. A functional anatomical study of unipolar depression. J Neurosci. 1992;12:3628-1.

16. Anacker C, Scholz J, O'Donnell KJ, Allemang-Grand R, Diorio J, Bagot RC, et al. Neuroanatomic differences associated with stress susceptibility and resilience. Biol Psychiatry. 2016;79:840-49.

17. Malone DA, Dougherty DD, Rezai AR, Carpenter LL, Friehs GM, Eskandar EN, et al. Deep brain stimulation of the ventral capsule/ventral striatum for treatment-resistant depression. Biol Psychiatry. 2009;65:267-75.

18. Dougherty DD, Rezai AR, Carpenter LL, Howland RH, Bhati MT, O'Reardon JP, et al. A randomized sham-controlled trial of deep brain stimulation of the ventral capsule/ventral striatum for chronic treatment-resistant depression. Biol Psychiatry. 2015;78:240-8.

19. Russo SJ, Nestler EJ. The brain reward circuitry in mood disorders. Nat Rev Neurosci. 2013;14:609-25.

20. Nestler EJ. Role of the brain's reward circuitry in depression: transcriptional mechanisms. Int Rev Neurobiol. 2015;124:151-70.
21. Chaudhury D, Walsh JJ, Friedman AK, Juarez B, Ku SM, Koo JW, et al. Rapid regulation of depression-related behaviours by control of midbrain dopamine neurons. Nature. 2013;493:532-6.

22. van Zessen R, Phillips JL, Budygin EA, Stuber GD. Activation of VTA GABA neurons disrupts reward consumption. Neuron. 2012;73:1184-94.

23. Stopper CM, Tse MTL, Montes DR, Wiedman CR, Floresco SB. Overriding phasic dopamine signals redirects action selection during risk/reward decision making. Neuron. 2014;84:177-89.

24. Hikosaka O. The habenula: from stress evasion to value-based decision-making. Nat Rev Neurosci. 2010;11:503-13.

25. Li B, Piriz J, Mirrione M, Chung C, Proulx CD, Schulz D, et al. Synaptic potentiation onto habenula neurons in the learned helplessness model of depression. Nature. 2011;470:535-41.

26. Shumake J, Gonzalez-Lima F. Brain systems underlying susceptibility to helplessness and depression. Behav Cogn Neurosci Rev. 2003;2:198-221.

27. Matsumoto M, Hikosaka O. Lateral habenula as a source of negative reward signals in dopamine neurons. Nature. 2007;447:1111-5.

28. Kaufling J, Veinante P, Pawlowski SA, Freund-Mercier M-J, Barrot M. Afferents to the GABAergic tail of the ventral tegmental area in the rat. J Comp Neurol. 2009;513:597-621.

29. Jhou TC, Geisler S, Marinelli M, Degarmo BA, Zahm DS. The mesopontine rostromedial tegmental nucleus: a structure targeted by the lateral habenula that projects to the ventral tegmental area of Tsai and substantia nigra compacta. J Comp Neurol. 2009;513:566-96.

30. Lazaridis I, Tzortzi O, Weglage M, Märtin A, Xuan Y, Parent M, et al. A hypothalamus-habenula circuit controls aversion. Mol Psychiatry. 2019;24:1351-68.

31. Deisseroth K. Circuit dynamics of adaptive and maladaptive behaviour. Nature. 2014;505:309-17.

32. Berton O, Nestler EJ. New approaches to antidepressant drug discovery: beyond monoamines. Nat Rev Neurosci. 2006;7: 137-51.

33. Andén N, Dahlström E, Fuxe A, Larsson K, Olson L, Ungerstedt $\mathrm{U}$. Ascending monoamine neurons to the telencephalon and diencephalon. Acta Physiol Scand. 1966;22:44-5.

34. Loomer HP, Saunders JC, Kliine NS. A clinical and pharmacodynamic evaluation of iproniazid as a psychic energizer. Psychiatr Res Rep Am Psychiatr Assoc. 1957;8:129-41.

35. Kuhn R. The treatment of depressive states with G 22355 (imipramine hydrochloride). Am J Psychiatry. 1958;115:459-64.

36. Axelrod J, Whitby LG, Hertting G. Effect of psychotropic drugs on the uptake of H3-norepinephrine by tissues. Science. 1961; 133:383-84.

37. Schildkraut JJ. The catecholamine hypothesis of affective disorders: a review of supporting evidence. Am J Psychiatry. 1965; 122:509-22.

38. Fuxe K, Dahlström A, Höistad M, Marcellino D, Jansson A, Rivera A, et al. From the Golgi-Cajal mapping to the transmitterbased characterization of the neuronal networks leading to two modes of brain communication: wiring and volume transmission. Brain Res Rev. 2007;55:17-54.

39. Schwarz LA, Luo L. Organization of the locus coeruleusnorepinephrine system. Curr Biol. 2015;25:R1051-56.

40. Coppen A. The biochemistry of affective disorders. Br J Psychiatry. 1967;113:1237-64.

41. Sugiyama E, Guerrini MM, Honda K, Hattori Y, Abe M, Källback P, et al. Detection of a high-turnover serotonin circuit in the mouse brain using mass spectrometry imaging. IScience. 2019;20:359-72.

42. Ren J, Isakova A, Friedmann D, Zeng J, Grutzner SM, Pun A, et al. Single-cell transcriptomes and whole-brain projections of serotonin neurons in the mouse dorsal and median raphe nuclei. Elife. 2019;8:e49424. 
43. Millan MJ. Multi-target strategies for the improved treatment of depressive states: conceptual foundations and neuronal substrates, drug discovery and therapeutic application. Pharm Ther. 2006;110:135-370.

44. Gerfen CR, Surmeier DJ. Modulation of striatal projection systems by dopamine. Annu Rev Neurosci. 2011;34:441-66.

45. Gerfen CR, Engber TM, Mahan LC, Susel Z, Chase TN, Monsma FJ, et al. D1 and D2 dopamine receptor-regulated gene expression of striatonigral and striatopallidal neurons. Science. 1990;250:1429-32.

46. Le Moine C, Bloch B. Expression of the $\mathrm{d} 3$ dopamine receptor in peptidergic neurons of the nucleus accumbens: comparison with the D1 and D2 dopamine receptors. Neuroscience. 1996;73:131-43.

47. Meador-Woodruff JH, Mansour A, Healy DJ, Kuehn R, Zhou QY, Bunzow JR, et al. Comparison of the distributions of D1 and D2 dopamine receptor mRNAs in the rat brain. Neuropsychopharmacology. 1991;5:231-42.

48. Gagnon D, Petryszyn S, Sanchez MG, Bories C, Beaulieu JM, De Koninck Y, et al. Striatal neurons expressing D1 and D2 receptors are morphologically distinct and differently affected by dopamine denervation in mice. Sci Rep. 2017;7:41432.

49. Francis TC, Chandra R, Friend DM, Finkel E, Dayrit G, Miranda $\mathrm{J}$, et al. Nucleus accumbens medium spiny neuron subtypes mediate depression-related outcomes to social defeat stress. Biol Psychiatry. 2015;77:212-22.

50. Soares-Cunha C, de Vasconcelos NAP, Coimbra B, Domingues AV, Silva JM, Loureiro-Campos E, et al. Nucleus accumbens medium spiny neurons subtypes signal both reward and aversion. Mol Psychiatry. 2019. https://doi.org/10.1038/s41380-019-0484-3.

51. Duman RS, Sanacora G, Krystal JH. Altered connectivity in depression: GABA and glutamate neurotransmitter deficits and reversal by novel treatments. Neuron. 2019;102:75-90.

52. Holmes SE, Scheinost D, Finnema SJ, Naganawa M, Davis MT, DellaGioia N, et al. Lower synaptic density is associated with depression severity and network alterations. Nat Commun. 2019;10:1529.

53. Zanos P, Piantadosi SC, Wu HQ, Pribut HJ, Dell MJ, Can A, et al. The prodrug 4-chlorokynurenine causes ketamine-like antidepressant effects, but not side effects, by NMDA/glycineBsite inhibitionS. J Pharm Exp Ther. 2015;355:76-85.

54. Samuels BA, Nautiyal KM, Kruegel AC, Levinstein MR, Magalong VM, Gassaway MM, et al. The behavioral effects of the antidepressant tianeptine require the $\mathrm{Mu}$-opioid receptor. Neuropsychopharmacology. 2017;42:2052-63.

55. Yksel C, Öngür D. Magnetic resonance spectroscopy studies of glutamate-related abnormalities in mood disorders. Biol Psychiatry. 2010;68:785-94.

56. Wise T, Cleare AJ, Herane A, Young AH, Arnone D. Diagnostic and therapeutic utility of neuroimaging in depression: an overview. Neuropsychiatr Dis Treat. 2014;10:1509-22.

57. Murrough JW, Abdallah CG, Mathew SJ. Targeting glutamate signalling in depression: progress and prospects. Nat Rev Drug Discov. 2017;16:472-86.

58. Luykx JJ, Laban KG, van den Heuvel MP, Boks MPM, Mandl $\mathrm{RCW}$, Kahn RS, et al. Region and state specific glutamate downregulation in major depressive disorder: a meta-analysis of 1H-MRS findings. Neurosci Biobehav Rev. 2012;36:198-205.

59. Crane GE. Cyloserine as an antidepressant agent. Am J Psychiatry. 1959;115:1025-6.

60. Berman RM, Cappiello A, Anand A, Oren DA, Heninger GR, Charney DS, et al. Antidepressant effects of ketamine in depressed patients. Biol Psychiatry. 2000;47:351-4.

61. Alexander SPH, Christopoulos A, Davenport AP, Kelly E, Mathie A, Peters JA, et al. The concise guide to pharmacology 2019/20: G protein-coupled receptors. Br J Pharmacol. 2019;176:S21-141.
62. Kobilka BK. G protein coupled receptor structure and activation. Biochim Biophys Acta Biomembr. 2007;1768:794-807.

63. Munk C, Isberg V, Mordalski S, Harpsøe K, Rataj K, Hauser AS, et al. GPCRdb: the $\mathrm{G}$ protein-coupled receptor database-an introduction. Br J Pharmacol. 2016;173:2195-207.

64. Hilger D, Masureel M, Kobilka BK. Structure and dynamics of GPCR signaling complexes. Nat Struct Mol Biol. 2018;25:4-12.

65. Farrens DL, Altenbach C, Yang K, Hubbell WL, Khorana HG. Requirement of rigid-body motion of transmembrane helices for light activation of rhodopsin. Science. 1996;274:768-770.

66. Weis WI, Kobilka BK. The molecular basis of G protein-coupled receptor activation. Annu Rev Biochem. 2014;87:897-919.

67. Rasmussen SGF, DeVree BT, Zou Y, Kruse AC, Chung KY, Kobilka TS, et al. Crystal structure of the $\beta 2$ adrenergic receptor-Gs protein complex. Nature. 2011;477:549-55.

68. Gurevich VV, Gurevich EV. GPCR signaling regulation: the role of GRKs and arrestins. Front Pharmacol. 2019;10:125.

69. Inoue A, Raimondi F, Kadji FMN, Singh G, Kishi T, Uwamizu A, et al. Illuminating G-protein-coupling selectivity of GPCRs. Cell. 2019;177:1933-47.e25.

70. DeWire SM, Ahn S, Lefkowitz RJ, Shenoy SK. Beta-arrestins and cell signaling. Annu Rev Physiol. 2007;69:483-510.

71. Santos R, Ursu O, Gaulton A, Bento AP, Donadi RS, Bologa $\mathrm{CG}$, et al. A comprehensive map of molecular drug targets. Nat Rev Drug Discov. 2017;16:19-34.

72. Hauser AS, Chavali S, Masuho I, Jahn LJ, Martemyanov KA, Gloriam DE, et al. Pharmacogenomics of GPCR drug targets. Cell. 2018;172:41-54.e19.

73. Sriram K, Insel PAG. Protein-coupled receptors as targets for approved drugs: how many targets and how many drugs? Mol Pharmacol. 2018;93:2518.

74. Lyu J, Wang S, Balius TE, Singh I, Levit A, Moroz YS, et al. Ultra-large library docking for discovering new chemotypes. Nature. 2019;566:224-9.

75. Stein RM, Kang HJ, McCorvy JD, Glatfelter GC, Jones AJ, Che $\mathrm{T}$, et al. Virtual discovery of melatonin receptor ligands to modulate circadian rhythms. Nature. 2020;579:609-14.

76. Liu L, Jockers R. Structure-based virtual screening accelerates GPCR drug discovery. Trends Pharm Sci. 2020;41:382-4.

77. Samuels BA, Anacker C, Hu A, Levinstein MR, Pickenhagen A, Tsetsenis $\mathrm{T}$, et al. 5-HT1A receptors on mature dentate gyrus granule cells are critical for the antidepressant response. Nat Neurosci. 2015;18:1606-16.

78. Racagni G, Popoli M. Cellular and molecular mechanisms in the long-term action of antidepressants. Dialogues Clin Neurosci. 2008;10:385-400.

79. Dale E, Bang-Andersen B, Sánchez C. Emerging mechanisms and treatments for depression beyond SSRIs and SNRIs. Biochem Pharmacol. 2015;95:81-97.

80. Kalia LV, Lang AE. Parkinson's disease. Lancet. 2015;386: 896-912.

81. Fawcett J, Rush AJ, Vukelich J, Diaz SH, Dunklee L, Romo P, et al. Clinical experience with high-dosage pramipexole in patients with treatment-resistant depressive episodes in unipolar and bipolar depression. Am J Psychiatry. 2016;173:107-11.

82. Solmi M, Veronese N, Zaninotto L, Van Der Loos MLM, Gao K, Schaffer A, et al. Lamotrigine compared to placebo and other agents with antidepressant activity in patients with unipolar and bipolar depression: a comprehensive meta-analysis of efficacy and safety outcomes in short-term trials. CNS Spectr. 2016;21:403-18.

83. Mathew SJ, Gueorguieva R, Brandt C, Fava M, Sanacora G. A randomized, double-blind, placebo-controlled, sequential parallel comparison design trial of adjunctive riluzole for treatmentresistant major depressive disorder. Neuropsychopharmacology. 2017;42:2567-74. 
84. Pittenger C, Vladimir C, Banasr M, Bloch M, Krystal JH, Sanacora G. Riluzole in the treatment of mood and anxiety disorders. CNS Drugs. 2008;22:761-86.

85. Abdallah CG, Averill LA, Krystal JH. Ketamine as a promising prototype for a new generation of rapid-acting antidepressants. Ann N. Y Acad Sci. 2015;1344:66-77.

86. Cui Y, Hu S, Hu H. Lateral habenular burst firing as a target of the rapid antidepressant effects of ketamine. Trends Neurosci. 2019;42:179-91.

87. Yang Y, Cui Y, Sang K, Dong Y, Ni Z, Ma S, et al. Ketamine blocks bursting in the lateral habenula to rapidly relieve depression. Nature. 2018;554:317-22.

88. Pothula S, Kato T, Liu R-J, Wu M, Gerhard D, Shinohara R, et al. Cell-type specific modulation of NMDA receptors triggers antidepressant actions. Mol Psychiatry. 2020. https://doi.org/10. 1038/s41380-020-0796-3.

89. Gerhard DM, Pothula S, Liu R-J, Wu M, Li X-Y, Girgenti MJ, et al. GABA interneurons are the cellular trigger for ketamine's rapid antidepressant actions. J Clin Investig. 2020;130:1336-49.

90. Zhou ZQ, Zhang GF, Li XM, Liu XY, Wang N, Qiu LL, et al. Loss of phenotype of parvalbumin interneurons in rat prefrontal cortex is involved in antidepressant- and propsychotic-like behaviors following acute and repeated ketamine administration. Mol Neurobiol. 2015;51:808-19.

91. Maeng S, Zarate CA, Du J, Schloesser RJ, McCammon J, Chen G, et al. Cellular mechanisms underlying the antidepressant effects of ketamine: role of $\alpha$-amino-3-hydroxy-5-methylisoxazole-4-propionic acid receptors. Biol Psychiatry. 2008;63:349-52.

92. Kiselycznyk C, Jury NJ, Halladay LR, Nakazawa K, Mishina M, Sprengel R, et al. NMDA receptor subunits and associated signaling molecules mediating antidepressant-related effects of NMDA-GluN2B antagonism. Behav Brain Res. 2015;287:89-95.

93. Newport DJ, Carpenter LL, McDonald WM, Potash JB, Tohen $\mathrm{M}$, Nemeroff CB. Ketamine and other NMDA antagonists: early clinical trials and possible mechanisms in depression. Am J Psychiatry. 2015;172:950-66.

94. Zanos P, Moaddel R, Morris PJ, Georgiou P, Fischell J, Elmer GI, et al. NMDAR inhibition-independent antidepressant actions of ketamine metabolites. Nature. 2016;533:481-6.

95. Zanos P, Highland JN, Stewart BW, Georgiou P, Jenne CE, Lovett J, et al. 2R,6R)-hydroxynorketamine exerts mGlu2 receptordependent antidepressant actions. Proc Natl Acad Sci USA. 2019;116:6441-50.

96. Podkowa K, Pochwat B, Brański P, Pilc A, Pałucha-Poniewiera A. Group II mGlu receptor antagonist LY341495 enhances the antidepressant-like effects of ketamine in the forced swim test in rats. Psychopharmacology. 2016;233:2901-14.

97. Swanson CJ, Bures M, Johnson MP, Linden A-M, Monn JA, Schoepp DD. Metabotropic glutamate receptors as novel targets for anxiety and stress disorders. Nat Rev Drug Discov. 2005;4:131-44.

98. Kenakin T. Biased receptor signaling in drug discovery. Pharm Rev. 2019;71:267-315.

99. Urban JD, Clarke WP, von Zastrow M, Nichols DE, Kobilka B, Weinstein $\mathrm{H}$, et al. Functional selectivity and classical concepts of quantitative pharmacology. J Pharm Exp Ther. 2007;320:1-13.

100. Kenakin T, Christopoulos A. Signalling bias in new drug discovery: detection, quantification and therapeutic impact. Nat Rev Drug Discov. 2013;12:205-16.

101. Smith JS, Lefkowitz RJ, Rajagopal S. Biased signalling: from simple switches to allosteric microprocessors. Nat Rev Drug Discov. 2018;17:243-60.

102. Rudmann DG. On-target and off-target-based toxicologic effects. Toxicol Pathol. 2012;41:310-4.

103. Michel MC, Charlton SJ. Biased agonism in drug discovery-is it too soon to choose a path? Mol Pharmacol. 2018;93:259-65.
104. Martin WR, Eades CG, Thompson JA, Huppler RE, Gilbert PE. The effects of morphine- and nalorphine- like drugs in the nondependent and morphine-dependent chronic spinal dog. J Pharm Exp Ther. 1976;197:517-32.

105. Bohn LM, et al. Enhanced morphine analgesia in mice lacking $\beta$ arrestin 2. Science. 1999;286:2495-8.

106. Bohn LM, Gainetdinov RR, Lin F-T, Lefkowitz RJ, Caron MG. $\mu-$ opioid receptor desensitization by $\beta$-arrestin- 2 determines morphine tolerance but not dependence. Nature. 2000;408:720-3.

107. Kelly E. Efficacy and ligand bias at the $\mu$-opioid receptor. $\mathrm{Br} \mathbf{J}$ Pharmacol. 2013;169:1430-46.

108. Kliewer A, Gillis A, Hill R, Schmiedel F, Bailey C, Kelly E, et al. Morphine-induced respiratory depression is independent of $\beta$-arrestin2 signalling. Br J Pharmacol. 2020;177:2923-31.

109. Kliewer A, Schmiedel F, Sianati S, Bailey A, Bateman JT, Levitt ES, et al. Phosphorylation-deficient G-protein-biased $\mu$-opioid receptors improve analgesia and diminish tolerance but worsen opioid side effects. Nat Commun. 2019;10:367.

110. DeWire SM, Yamashita DS, Rominger DH, Liu G, Cowan CL, Graczyk TM, et al. A G protein-biased ligand at the $\mu$-opioid receptor is potently analgesic with reduced gastrointestinal and respiratory dysfunction compared with morphine. J Pharm Exp Ther. 2013;344:708-17.

111. Michino M, Beuming T, Donthamsetti P, Newman AH, Javitch JA, Shi L. What can crystal structures of aminergic receptors tell us about designing subtype-selective ligands? Pharm Rev. 2015; 67:198-213.

112. Millan MJ. On 'polypharmacy' and multi-target agents, complementary strategies for improving the treatment of depression: a comparative appraisal. Int J Neuropsychopharmacol. 2014;17: 1009-37.

113. Corvol JC, Studler JM, Schonn JS, Girault JA, Hervé D. Goolf is necessary for coupling D1 and A2a receptors to adenylyl cyclase in the striatum. J Neurochem. 2001;76:1585-8.

114. Adrian Newman-Tancredi. Biased agonism at serotonin 5-HT1A receptors: preferential postsynaptic activity for improved therapy of CNS disorders. Neuropsychiatry. 2011;1:149-64.

115. Pardon E, Betti C, Laeremans T, Chevillard F, Guillemyn K, Kolb $\mathrm{P}$, et al. Nanobody-enabled reverse pharmacology on G-proteincoupled receptors. Angew Chem Int Ed. 2018;57:5292-5.

116. Gettys TW, Fields TA, Raymond JR. Selective activation of inhibitory G-protein.alpha.-subunits by partial agonists of the human 5-HT1A receptor. Biochemistry. 1994;33:4283-90.

117. Newman-Tancredi A, Cussac D, Marini L, Millan MJ. Antibody capture assay reveals bell-shaped concentration-response isotherms for h5-HT 1A receptor-mediated G $\alpha$ i3 activation: conformational selection by high-efficacy agonists, and relationship to trafficking of receptor signaling. Mol Pharmacol. 2002;62:590-601.

118. Newman-Tancredi A, Martel J-C, Assié M-B, Buritova J, Lauressergues E, Cosi C, et al. Signal transduction and functional selectivity of F15599, a preferential post-synaptic 5-HT1A receptor agonist. Br J Pharmacol. 2009;156:338-53.

119. Depoortère R, Auclair AL, Bardin L, Colpaert FC, Vacher B, Newman-Tancredi A. F15599, a preferential post-synaptic 5-HT1A receptor agonist: Activity in models of cognition in comparison with reference 5-HT1A receptor agonists. Eur Neuropsychopharmacol. 2010;20:641-54.

120. Lladó-Pelfort L, Assié M-B, Newman-Tancredi A, Artigas F, Celada P. Preferential in vivo action of F15599, a novel 5-HT1A receptor agonist, at postsynaptic 5-HT1A receptors. Br J Pharmacol. 2010;160:1929-40.

121. Jastrzębska-Więsek M, Partyka A, Rychtyk J, Śniecikowska J, Kołaczkowski M, Wesołowska A, et al. Activity of serotonin 5HT1A receptor biased agonists in rat: anxiolytic and antidepressantlike properties. ACS Chem Neurosci. 2018;9:1040-50. 
122. Pytka K, Głuch-Lutwin M, Żmudzka E, Sałaciak K, Siwek A. Niemczyk K, et al. HBK-17, a 5-HT(1A) receptor ligand with anxiolytic-like activity, preferentially activates $\beta$-arrestin signaling. Front Pharmacol. 2018;9:1146.

123. Palczewski K, Kumasaka T, Hori T, Behnke CA, Motoshima H, Fox BA, et al. Crystal structure of rhodopsin: a $\mathrm{G}$ protein-coupled receptor. Science. 2000;289:739-45.

124. Kimura KT, Asada H, Inoue A, Kadji FMN, Im D, Mori C, et al. Structures of the 5-HT2A receptor in complex with the antipsychotics risperidone and zotepine. Nat Struct Mol Biol. 2019;26:121-8.

125. Wacker D, Wang S, McCorvy JD, Betz RM, Venkatakrishnan AJ, Levit A, et al. Crystal structure of an LSD-bound human serotonin receptor. Cell. 2017;168:377-389.e12.

126. Peng Y, McCorvy JD, Harpsøe K, Lansu K, Yuan S, Popov P, et al. 5-HT2C receptor structures reveal the structural basis of GPCR polypharmacology. Cell. 2018;172:719-30.e14.

127. McCorvy JD, Wacker D, Wang S, Agegnehu B, Liu J, Lansu K, et al. Structural determinants of 5-HT2B receptor activation and biased agonism. Nat Struct Mol Biol. 2018;25:787-96.

128. Nutt D, Erritzoe D, Carhart-Harris R. Psychedelic psychiatry's brave new world. Cell. 2020;181:24-8.

129. Griffiths RR, Johnson MW, Carducci MA, Umbricht A, Richards WA, Richards BD, et al. Psilocybin produces substantial and sustained decreases in depression and anxiety in patients with life-threatening cancer: a randomized double-blind trial. J Psychopharmacol. 2016;30:1181-97.

130. Carhart-Harris RL, Bolstridge M, Rucker J, Day CMJ, Erritzoe D, Kaelen M, et al. Psilocybin with psychological support for treatment-resistant depression: an open-label feasibility study. the Lancet. Psychiatry. 2016;3:619-27.

131. Davis AK, Barrett FS, May DG, Cosimano MP, Sepeda ND, Johnson MW, et al. Effects of psilocybin-assisted therapy on major depressive disorder: a randomized clinical trial. JAMA Psychiatry. 2020. https://doi.org/10.1001/jamapsychiatry.2020.3285.

132. Kim K, Che T, Panova O, DiBerto JF, Lyu J, Krumm BE, et al. Structure of a hallucinogen-activated Gq-coupled 5-HT2A serotonin receptor. Cell. 2020;182:1574-1588.e19.

133. Katritch V, Reynolds KA, Cherezov V, Hanson MA, Roth CB, Yeager M, et al. Analysis of full and partial agonists binding to beta2-adrenergic receptor suggests a role of transmembrane helix $\mathrm{V}$ in agonist-specific conformational changes. J Mol Recognit. 2009;22:307-18.

134. Che T, Majumdar S, Zaidi SA, Ondachi P, McCorvy JD, Wang $\mathrm{S}$, et al. Structure of the nanobody-stabilized active state of the kappa opioid receptor. Cell. 2018;172:55-67.e15.

135. McCorvy JD, Butler KV, Kelly B, Rechsteiner K, Karpiak J, Betz RM, et al. Structure-inspired design of $\beta$-arrestin-biased ligands for aminergic GPCRs. Nat Chem Biol. 2018;14:126-34.

136. Roth BL. Molecular pharmacology of metabotropic receptors targeted by neuropsychiatric drugs. Nat Struct Mol Biol. 2019; 26:535-44.

137. Rothman RB, Baumann MH, Savage JE, Rauser L, McBride A, Hufeisen SJ, et al. Evidence for possible involvement of 5-HT $2 \mathrm{~B}$ receptors in the cardiac valvulopathy associated with fenfluramine and other serotonergic medications. Circulation. 2000; 102:2836-41.

138. Zhou Q, Yang D, Wu M, Guo Y, Guo W, Zhong L, et al. Common activation mechanism of class A GPCRs. Elife. 2019;8:e50279.

139. McCorvy JD, Roth BL. Structure and function of serotonin G protein-coupled receptors. Pharm Ther. 2015;150:129-42.

140. Wu H, Wang C, Gregory KJ, Han GW, Cho HP, Xia Y, et al. Structure of a class C GPCR metabotropic glutamate receptor 1 bound to an allosteric modulator. Science. 2014;344:58-64.
141. Conn PJ, Christopoulos A, Lindsley CW. Allosteric modulators of GPCRs: a novel approach for the treatment of CNS disorders. Nat Rev Drug Discov. 2009;8:41-54.

142. Wootten D, Christopoulos A, Sexton PM. Emerging paradigms in GPCR allostery: implications for drug discovery. Nat Rev Drug Discov. 2013;12:630-44.

143. Straiker A, Mitjavila J, Yin D, Gibson A, Mackie K. Aiming for allosterism: evaluation of allosteric modulators of $\mathrm{CB} 1$ in a neuronal model. Pharm Res. 2015;99:370-6.

144. Ehlert FJ, Roeske WR, Gee KW, Yamamura HI. An allosteric model for benzodiazepine receptor function. Biochem Pharmacol. 1983;32:2375-83.

145. Anis NA, Berry SC, Burton NR, Lodge D. The dissociative anaesthetics, ketamine and phencyclidine, selectively reduce excitation of central mammalian neurones by $\mathrm{N}$-methyl-aspartate. $\mathrm{Br} \mathrm{J}$ Pharmacol. 1983;79:565-75.

146. Tatarczyńska E, Klodzińska A, Chojnacka-Wójcik E, Palucha A, Gasparini F, Kuhn R, et al. Potential anxiolytic- and antidepressantlike effects of MPEP, a potent, selective and systemically active mGlu5 receptor antagonist. Br J Pharmacol. 2001;132:1423-30.

147. Pałucha A, Brański P, Szewczyk B, Wierońska JM, Kłak K, Pilc A. Potential antidepressant-like effect of MTEP, a potent and highly selective mGluR5 antagonist. Pharm Biochem Behav. 2005;81:901-6.

148. Lee KW, Westin L, Kim J, Chang JC, Oh YS, Amreen B, et al. Alteration by $\mathrm{p} 11$ of mGluR5 localization regulates depressionlike behaviors. Mol Psychiatry. 2015;20:1546-56.

149. Quiroz JA, Tamburri P, Deptula D, Banken L, Beyer U, Rabbia $M$, et al. Efficacy and safety of basimglurant as adjunctive therapy for major depression: a randomized clinical trial. JAMA Psychiatry. 2016;73:675-84.

150. Hughes ZA, Neal SJ, Smith DL, Sukoff Rizzo SJ, Pulicicchio CM, Lotarski S, et al. Negative allosteric modulation of metabotropic glutamate receptor 5 results in broad spectrum activity relevant to treatment resistant depression. Neuropharmacology. 2013;66:202-14.

151. Campo B, Kalinichev M, Lambeng N, El YacoubiM, RoyerUrios I, Schneider M, et al. Characterization of an mGluR2/3 negative allosteric modulator in rodent models of depression. $\mathrm{J}$ Neurogenet. 2011;25:152-66.

152. Kent JM, Daly E, Kezic I, Lane R, Lim P, De Smedt H, et al. Efficacy and safety of an adjunctive mGlu2 receptor positive allosteric modulator to a SSRI/SNRI in anxious depression. Prog Neuropsychopharmacol Biol Psychiatry. 2016;67:66-73.

153. Fell MJ, Witkin JM, Falcone JF, Katner JS, Perry KW, Hart J, et al. N -(4-((2-(trifluoromethyl)-3-hydroxy-4-(isobutyryl)phenoxy)methyl)benzyl)-1-methyl-1 H -imidazole-4-carboxamide (THIIC), a Novel Metabotropic Glutamate 2 Potentiator with Potential Anxiolytic/Antidepressant Properties: In Vivo Profiling Suggests a Link b. J Pharm Exp Ther. 2011;336:165-77.

154. Joffe ME, Santiago CI, Oliver KH, Maksymetz J, Harris NA, Engers JL, et al. mGlu2 and mGlu3 negative allosteric modulators divergently enhance thalamocortical transmission and exert rapid antidepressant-like effects. Neuron. 2020;105:46-59.e3.

155. Roth BL, Sheffler DJ, Kroeze WK. Magic shotguns versus magic bullets: selectively non-selective drugs for mood disorders and schizophrenia. Nat Rev Drug Discov. 2004;3:353-59.

156. Peng L, Gu L, Li B, Hertz L. Fluoxetine and all other SSRIs are 5-HT2B agonists-importance for their therapeutic effects. Curr Neuropharmacol. 2014;12:365-79.

157. Diaz SL, Doly S, Narboux-Nême N, Fernández S, Mazot P, Banas SM, et al. 5-HT2B receptors are required for serotonin-selective antidepressant actions. Mol Psychiatry. 2012;17:154-63.

158. Monaca C, Boutrel B, Hen R, Hamon M, Adrien J. 5-HT1A/1B receptor-mediated effects of the selective serotonin reuptake 
inhibitor, citalopram, on sleep: studies in 5-HT1A and 5-HT1B Knockout Mice. Neuropsychopharmacology. 2003;28:850-6.

159. Chen J-F, Steyn S, Staal R, Petzer JP, Xu K, Van der Schyf CJ, et al. 8-(3-Chlorostyryl)caffeine may attenuate MPTP neurotoxicity through dual actions of monoamine oxidase inhibition and A2A receptor antagonism. J Biol Chem. 2002;277:36040-4.

160. Jaiteh M, Zeifman A, Saarinen M, Svenningsson $P$, Bréa J, Loza MI, et al. Docking screens for dual inhibitors of disparate drug targets for Parkinson's disease. J Med Chem. 2018;61:5269-78.

161. Seong HS, Paudel P, Choi J-W, Ahn HD, Nam T-J, Jung AH, et al. Probing multi-target action of phlorotannins as new monoamine oxidase inhibitors and dopaminergic receptor modulators with the potential for treatment of neuronal disorders. Mar Drugs. 2019;17:600.

162. Affini A, Hagenow S, Zivkovic A, Marco-Contelles J, Stark H. Novel indanone derivatives as MAO B/H3R dual-targeting ligands for treatment of Parkinson's disease. Eur J Med Chem. 2018;148:487-97.

163. Besnard J, Ruda GF, Setola V, Abecassis K, Rodriguiz RM, Huang X-P, et al. Automated design of ligands to polypharmacological profiles. Nature. 2012;492:215-20.

164. González-Maeso J. GPCR oligomers in pharmacology and signaling. Mol Brain. 2011;4:20.

165. Fuxe K, Borroto-Escuela DO, Romero-Fernandez W, Palkovits M, Tarakanov AO, Ciruela F, et al. Moonlighting proteins and protein-protein interactions as neurotherapeutic targets in the $G$ protein-coupled receptor field. Neuropsychopharmacology. 2014;39:131-55.

166. Fuxe K, Agnati LF, Benfenati F, Celani M, Zini I, Zoli MMV. Evidence for the existence of receptor-receptor interactions in the central nervous system. Studies on the regulation of monoamine receptors by neuropeptides. J Neural Transm Suppl. 1983; 18:165-79.

167. Pin J-P, Kniazeff J, Binet V, Liu J, Maurel D, Galvez T, et al. Activation mechanism of the heterodimeric GABAB receptor. Biochem Pharmacol. 2004;68:1565-72.

168. Terrillon S, Bouvier M. Roles of G-protein-coupled receptor dimerization. EMBO Rep. 2004;5:30-4.

169. Renner U, Zeug A, Woehler A, Niebert M, Dityatev A, Dityateva G, et al. Heterodimerization of serotonin receptors 5HT1A and 5-HT7 differentially regulates receptor signalling and trafficking. J Cell Sci. 2012;125:2486-99.

170. Fuxe K, Ferré S, Canals M, Torvinen M, Terasmaa A, Marcellino $\mathrm{D}$, et al. Adenosine A2A and dopamine D2 heteromeric receptor complexes and their function. J Mol Neurosci. 2005;26:209-20.

171. Fuxe K, Borroto-Escuela D, Romero-Fernandez W, Tarakanov A, Calvo F, Garriga P, et al. On the existence and function of galanin receptor heteromers in the central nervous system. Front Endocrinol. 2012;3:127.

172. Borroto-Escuela DO, Romero-Fernandez W, Mudó G, PérezAlea M, Ciruela F, Tarakanov AO, et al. Fibroblast growth factor receptor 1-5-hydroxytryptamine $1 \mathrm{~A}$ heteroreceptor complexes and their enhancement of hippocampal plasticity. Biol Psychiatry. 2012;71:84-91.

173. Borroto-Escuela DO, Corrales F, Narvaez M, Oflijan J, Agnati LF, Palkovits M, et al. Dynamic modulation of FGFR1-5-HT1A heteroreceptor complexes. Agonist treatment enhances participation of FGFR1 and 5-HT1A homodimers and recruitment of $\beta$ arrestin2. Biochem Biophys Res Commun. 2013;441:387-92.

174. Lee FJS, Xue S, Pei L, Vukusic B, Chéry N, Wang Y, et al. Dual regulation of NMDA receptor functions by direct protein-protein interactions with the dopamine D1 receptor. Cell. 2002;111:219-30.

175. Gomes I, Ayoub MA, Fujita W, Jaeger WC, Pfleger KDG, Devi LAG. Protein-coupled receptor heteromers. Annu Rev Pharm Toxicol. 2016;56:403-25.
176. Hübner H, Schellhorn T, Gienger M, Schaab C, Kaindl J, Leeb $\mathrm{L}$, et al. Structure-guided development of heterodimer-selective GPCR ligands. Nat Commun. 2016;7:12298.

177. Peterson CD, Kitto KF, Akgün E, Lunzer MM, Riedl MS, Vulchanova L, et al. Bivalent ligand that activates mu opioid receptor and antagonizes mGluR5 receptor reduces neuropathic pain in mice. Pain. 2017;158:2431-41.

178. Franco R, Martínez-Pinilla E, Ricobaraza A, McCormick PJ. Challenges in the development of heteromer-GPCR-based drugs. Prog Mol Biol Transl Sci. 2013;117:143-62.

179. Pei L, Li S, Wang M, Diwan M, Anisman H, Fletcher PJ, et al. Uncoupling the dopamine D1-D2 receptor complex exerts antidepressant-like effects. Nat Med. 2010;16:1393-5.

180. Szafran K, Faron-Górecka A, Kolasa M, Kuśmider M, Solich J, Zurawek D, et al. Potential role of $\mathrm{G}$ protein-coupled receptor (GPCR) heterodimerization in neuropsychiatric disorders: a focus on depression. Pharm Rep. 2013;65:1498-1505.

181. Burman KD, Baker JRJ. Immune mechanisms in Graves' disease. Endocr Rev. 1985;6:183-232.

182. Biggs EK, Liang L, Naylor J, Madalli S, Collier R, Coghlan MP, et al. Development and characterisation of a novel glucagon like peptide-1 receptor antibody. Diabetologia. 2018;61:711-21.

183. Li C, Yang M, Wang X, Zhang H, Yao C, Sun S, et al. Glutazumab, a novel long-lasting GLP-1/anti-GLP-1R antibody fusion protein, exerts anti-diabetic effects through targeting dual receptor binding sites. Biochem Pharmacol. 2018;150:46-53.

184. Scott MJ, Jowett A, Orecchia M, Ertl P, Ouro- L, Ticehurst J, et al. Rapid identification of highly potent human anti- GPCR antagonist monoclonal antibodies. MAbs. 2020;12:1755069.

185. Platt MP, Agalliu D, Cutforth T. Hello from the other side: how autoantibodies circumvent the blood-brain barrier in autoimmune encephalitis. Front Immunol. 2017;8:442.

186. Lancaster E, Martinez-Hernandez E, Titulaer MJ, Boulos M, Weaver S, Antoine J-C, et al. Antibodies to metabotropic glutamate receptor 5 in the Ophelia syndrome. Neurology. 2011;77:1698-1701.

187. Najjar S, Pearlman DM, Devinsky O, Najjar A, Zagzag D. Neurovascular unit dysfunction with blood-brain barrier hyperpermeability contributes to major depressive disorder: a review of clinical and experimental evidence. J Neuroinflammation. 2013;10:906.

188. Menard C, Pfau ML, Hodes GE, Kana V, Wang VX, Bouchard $\mathrm{S}$, et al. Social stress induces neurovascular pathology promoting depression. Nat Neurosci. 2017;20:1752-60.

189. Yu YJ, Zhang Y, Kenrick M, Hoyte K, Luk W, Lu Y, et al. Boosting brain uptake of a therapeutic antibody by reducing its affinity for a transcytosis target. Sci Transl Med. 2011;3:84ra44.

190. Atwal JK, Chen Y, Chiu C, Mortensen DL, Meilandt WJ, Liu Y, et al. A therapeutic antibody targeting BACE1 inhibits amyloid- $\beta$ production in vivo. Sci Transl Med. 2011;3:84ra43.

191. Neves V, Aires-da-Silva F, Corte-Real S, Castanho MARB. Antibody approaches to treat brain diseases. Trends Biotechnol. 2016;34:36-48.

192. Edvinsson L, Haanes KA, Warfvinge K, Krause DN. CGRP as the target of new migraine therapies-successful translation from bench to clinic. Nat Rev Neurol. 2018;14:338-50.

193. Giamberardino MA, Affaitati G, Costantini R, Cipollone F, Martelletti P. Calcitonin gene-related peptide receptor as a novel target for the management of people with episodic migraine: current evidence and safety profile of erenumab. J Pain Res. 2017;10:2751-60.

194. Plouffe B, Thomsen ARB, Irannejad R. Emerging role of compartmentalized $\mathrm{G}$ protein-coupled receptor signaling in the cardiovascular field. ACS Pharm Transl Sci. 2020;3:221-36.

195. Martin RD, Sun Y, Bourque K, Audet N, Inoue A, Tanny JC, et al. Receptor- and cellular compartment-specific activation of 
the cAMP/PKA pathway by $\alpha 1$-adrenergic and ETA endothelin receptors. Cell Signal. 2018;44:43-50.

196. Suofu Y, Li W, Jean-Alphonse FG, Jia J, Khattar NK, Li J, et al. Dual role of mitochondria in producing melatonin and driving GPCR signaling to block cytochrome c release. Proc Natl Acad Sci. 2017;114:E7997-E8006.

197. Jensen DD, Lieu T, Halls ML, Veldhuis NA, Imlach WL, Mai QN, et al. Neurokinin 1 receptor signaling in endosomes mediates sustained nociception and is a viable therapeutic target for prolonged pain relief. Sci Transl Med. 2017;9:eaal3447.

198. Godbole A, Lyga S, Lohse MJ, Calebiro D. Internalized TSH receptors en route to the TGN induce local Gs-protein signaling and gene transcription. Nat Commun. 2017;8:443.

199. Bénard G, Massa F, Puente N, Lourenço J, Bellocchio L, SoriaGómez E, et al. Mitochondrial CB1 receptors regulate neuronal energy metabolism. Nat Neurosci. 2012;15:558-64.

200. Ramírez-García PD, Retamal JS, Shenoy P, Imlach W, Sykes M, Truong N, et al. A pH-responsive nanoparticle targets the neurokinin 1 receptor in endosomes to prevent chronic pain. Nat Nanotechnol. 2019;14:1150-9.

201. Underhill SM, Hullihen PD, Chen J, Fenollar-Ferrer C, Rizzo MA, Ingram SL, et al. Amphetamines signal through intracellular TAAR1 receptors coupled to $\mathrm{G} \alpha 13$ and $\mathrm{G} \alpha \mathrm{S}$ in discrete subcellular domains. Mol Psychiatry. 2019. https://doi.org/10.1038/ s41380-019-0469-2.

202. Björk K, Svenningsson P. Modulation of monoamine receptors by adaptor proteins and lipid rafts: role in some effects of centrally acting drugs and therapeutic agents. Annu Rev Pharm Toxicol. 2011;51:211-242.

203. Lipton RB, Dodick DW, Ailani J, Lu K, Finnegan M, Szegedi A, et al. Effect of ubrogepant vs placebo on pain and the most bothersome associated symptom in the acute treatment of migraine: the achieve ii randomized clinical trial. JAMA. 2019;322:1887-98.

204. Brakeman PR, Lanahan AA, O'Brien R, Roche K, Barnes CA, Huganir RL, et al. Homer: a protein that selectively binds metabotropic glutamate receptors. Nature. 1997;386:284-8.

205. Serchov T, Clement H-W, Schwarz MK, Iasevoli F, Tosh DK, Idzko $\mathrm{M}$, et al. Increased signaling via adenosine A1 receptors, sleep deprivation, imipramine, and ketamine inhibit depressive-like behavior via induction of Homerla. Neuron. 2015;87:549-62.

206. Holz A, Mülsch F, Schwarz MK, Hollmann M, Döbrössy MD, Coenen VA, et al. Enhanced mGlu5 signaling in excitatory neurons promotes rapid antidepressant effects via AMPA receptor activation. Neuron. 2019;104:338-52.e7.

207. Rietschel M, Mattheisen M, Frank J, Treutlein J, Degenhardt F, Breuer R, et al. Genome-wide association-, replication-, and neuroimaging study implicates HOMER1 in the etiology of major depression. Biol Psychiatry. 2010;68:578-85.

208. Seo J-S, Svenningsson P. Modulation of ion channels and receptors by p11 (S100A10). Trends Pharm Sci. 2020;41:487-97.

209. Anisman H, Du L, Palkovits M, Faludi G, Kovacs GG, Szontagh-Kishazi P, et al. Serotonin receptor subtype and p11 mRNA expression in stress-relevant brain regions of suicide and control subjects. J Psychiatry Neurosci. 2008;33:131-141.

210. Alexander B, Warner-Schmidt J, Eriksson T, Tamminga C, Arango-Llievano M, Ghose S, et al. Reversal of depressed behaviors in mice by p11 gene therapy in the nucleus accumbens. Sci Transl Med. 2010;2:54ra76.

211. Svenningsson P, Chergui K, Rachleff I, Flajolet M, Zhang X, El Yacoubi M, et al. Alterations in 5-HT1B receptor function by p11 in depression-like states. Science. 2006;311:77-80.

212. Warner-Schmidt JL, Schmidt EF, Marshall JJ, Rubin AJ, Arango-Lievano M, Kaplitt MG, et al. Cholinergic interneurons in the nucleus accumbens regulate depression-like behavior. Proc Natl Acad Sci USA. 2012;109:11360-5.
213. Egeland M, Warner-Schmidt J, Greengard P, Svenningsson P. Co-expression of serotonin 5-HT1B and 5-HT4 receptors in p11 containing cells in cerebral cortex, hippocampus, caudateputamen and cerebellum. Neuropharmacology. 2011;61:442-50.

214. Warner-Schmidt JL, Flajolet M, Maller A, Chen EY, Qi H, Svenningsson $\mathrm{P}$, et al. Role of $\mathrm{p} 11$ in cellular and behavioral effects of 5-HT4 receptor stimulation. J Neurosci. 2009;29:1937-46.

215. Medrihan L, Sagi Y, Inde Z, Krupa O, Daniels C, Peyrache A, et al. Initiation of behavioral response to antidepressants by cholecystokinin neurons of the dentate gyrus. Neuron. 2017;95:564-76.

216. Sargin D, Chottekalapanda RU, Perit KE, Yao V, Chu D, Sparks DW, et al. Mapping the physiological and molecular markers of stress and SSRI antidepressant treatment in S100a10 corticostriatal neurons. Mol Psychiatry. 2020;25:1112-29.

217. Schmidt EF, Warner-Schmidt JL, Otopalik BG, Pickett SB, Greengard P, Heintz N. Identification of the cortical neurons that mediate antidepressant responses. Cell. 2012;149:1152-63.

218. Oh SJ, Cheng J, Jang JH, Arace J, Jeong M, Shin CH, et al. Hippocampal mossy cell involvement in behavioral and neurogenic responses to chronic antidepressant treatment. Mol Psychiatry. 2020;25:1215-28.

219. Sun HL, Zhou ZQ, Zhang GF, Yang C, Wang XM, Shen JC, et al. Role of hippocampal p11 in the sustained antidepressant effect of ketamine in the chronic unpredictable mild stress model. Transl Psychiatry. 2016;6:e741.

220. Oh Y-S, Gao P, Lee K-W, Ceglia I, Seo J-S, Zhang X, et al. SMARCA3, a chromatin-remodeling factor, is required for $\mathrm{p} 11$ dependent antidepressant action. Cell. 2013;152:831-43.

221. Jin J, Bhatti DL, Lee KW, et al. Ahnak scaffolds p11/Anxa2 complex and L-type voltage-gated calcium channel and modulates depressive behavior. Mol Psychiatry. 2020;25:1035-1049.

222. Lang R, Gundlach AL, Holmes FE, Hobson SA, Wynick D, Hökfelt $T$, et al. Physiology, signaling, and pharmacology of galanin peptides and receptors: three decades of emerging diversity. Pharm Rev. 2015;67:118-75.

223. Kuteeva E, Hökfelt T, Wardi T, Ögren SOGalanin. Galanin receptor subtypes and depression-like behaviour. Cell Mol Life Sci. 2008;65:1854-63.

224. Lu X, Ross B, Sanchez-Alavez M, Zorrilla EP, Bartfai T. Phenotypic analysis of GalR2 knockout mice in anxiety- and depressionrelated behavioral tests. Neuropeptides. 2008;42:387-97.

225. Le Maître TW, Xia S, Le Maitre E, Dun X-P, Lu J, Theodorsson E, et al. Galanin receptor 2 overexpressing mice display an antidepressive-like phenotype: possible involvement of the subiculum. Neuroscience. 2011;190:270-88.

226. Wang $\mathrm{P}$, Li H, Barde S, Zhang M-D, Sun J, Wang T, et al. Depression-like behavior in rat: Involvement of galanin receptor subtype 1 in the ventral periaqueductal gray. Proc Natl Acad Sci. 2016;113:E4726 LP-E4735.

227. Heilig M. The NPY system in stress, anxiety and depression. Neuropeptides. 2004;38:213-24.

228. Wu G, Feder A, Wegener G, Bailey C, Saxena S, Charney D, et al. Central functions of neuropeptide $\mathrm{Y}$ in mood and anxiety disorders. Expert Opin Ther Targets. 2011;15:1317-31.

229. Goyal SN, Upadhya MA, Kokare DM, Bhisikar SM, Subhedar NK. Neuropeptide Y modulates the antidepressant activity of imipramine in olfactory bulbectomized rats: involvement of NPY Y1 receptors. Brain Res. 2009;1266:45-53.

230. Redrobe JP, Dumont Y, Fournier A, Quirion R. The neuropeptide Y (NPY) Y1 receptor subtype mediates NPY-induced antidepressant-like activity in the mouse forced swimming test. Neuropsychopharmacol Publ Am Coll Neuropsychopharmacol. 2002;26:615-24.

231. Domin H, Szewczyk B, Pochwat B, Woźniak M, Śmiałowska M. Antidepressant-like activity of the neuropeptide Y Y5 receptor 
antagonist Lu AA33810: behavioral, molecular, and immunohistochemical evidence. Psychopharmacology. 2017;234:631-45.

232. Walker MW, Wolinsky TD, Jubian V, Chandrasena G, Zhong H, Huang X, et al. The novel neuropeptide Y Y5 receptor antagonist Lu AA33810 [N-[[trans-4-[(4,5-dihydro[1]benzothiepino[5,4-d] thiazol-2-yl)amino]cyclohexyl]methyl]-methanesulfonamide] exerts anxiolytic- and antidepressant-like effects in rat models of stress sensitivity. J Pharmacol Exp Ther. 2009;328:900-11.

233. Cox EQ, Stuebe A, Pearson B, Grewen K, Rubinow D, MeltzerBrody S. Oxytocin and HPA stress axis reactivity in postpartum women. Psychoneuroendocrinology. 2015;55:164-72.

234. Scantamburlo G, Hansenne M, Fuchs S, Pitchot W, Maréchal P, Pequeux C, et al. Plasma oxytocin levels and anxiety in patients with major depression. Psychoneuroendocrinology. 2007;32:407-10.

235. Arletti R, Bertolini A. Oxytocin acts as an antidepressant in two animal models of depression. Life Sci. 1987;41:1725-30.

236. Wang T, Shi C, Li X, Zhang P, Liu B, Wang H, et al. Injection of oxytocin into paraventricular nucleus reverses depressive-like behaviors in the postpartum depression rat model. Behav Brain Res. 2018;336:236-43.

237. Komatsu H, Maruyama M, Yao S, Shinohara T, Sakuma K, Imaichi $S$, et al. Anatomical transcriptome of $\mathrm{G}$ protein-coupled receptors leads to the identification of a novel therapeutic candidate gpr52 for psychiatric disorders. PLoS ONE. 2014;9:e90134.

238. Boehm C, Newrzella D, Herberger S, Schramm N, Eisenhardt G, Schenk V, et al. Effects of antidepressant treatment on gene expression profile in mouse brain: cell type-specific transcription profiling using laser microdissection and microarray analysis. $\mathrm{J}$ Neurochem. 2006;97:44-9.

239. Conti B, Maier R, Barr AM, Morale MC, Lu X, Sanna PP, et al. Region-specific transcriptional changes following the three antidepressant treatments electro convulsive therapy, sleep deprivation and fluoxetine. Mol Psychiatry. 2007;12:167-89.

240. Mizushima K, Miyamoto Y, Tsukahara F, Hirai M, Sakaki Y, Ito T. A novel G-protein-coupled receptor gene expressed in striatum. Genomics. 2000;69:314-21.

241. Quintana A, Sanz E, Wang W, Storey GP, Güler AD, Wanat MJ, et al. Lack of GPR88 enhances medium spiny neuron activity and alters motor- and cue-dependent behaviors. Nat Neurosci. 2012;15:1547-55.

242. Massart R, Guilloux JP, Mignon V, Sokoloff P, Diaz J. Striatal GPR88 expression is confined to the whole projection neuron population and is regulated by dopaminergic and glutamatergic afferents. Eur J Neurosci. 2009;30:397-14.

243. Meirsman AC, Robé A, de Kerchove D'Exaerde A, Kieffer BL. GPR88 in A2AR neurons enhances anxiety-like behaviors. eNeuro. 2016;3:ENEURO.0202-16.2016.

244. Meirsman AC, Ben Hamida S, Clarke E, de Kerchove d'Exaerde A, Darcq E, Kieffer BL. GPR88 in D1R-type and D2R-type medium spiny neurons differentially regulates affective and motor behavior. eNeuro. 2019;6:ENEURO.0035-19.2019.

245. Mantas I, Yang Y, Mannoury-la-cour C, Millan MJ, Zhang X, Svenningsson P. Genetic deletion of GPR88 enhances the locomotor response to L-DOPA in experimental parkinsonism while counteracting the induction of dyskinesia. Neuropharmacology. 2020;162:107829.

246. Meirsman AC, Le Merrer J, Pellissier LP, Diaz J, Clesse D, Kieffer BL, et al. Mice lacking GPR88 show motor deficit, improved spatial learning, and low anxiety reversed by delta opioid antagonist. Biol Psychiatry. 2016;79:917-27.

247. Ye N, Li B, Mao Q, Wold EA, Tian S, Allen JA, et al. Orphan receptor GPR88 as an emerging neurotherapeutic target. ACS Chem Neurosci. 2019;10:190-200.

248. Reinius B, Blunder M, Brett FM, Eriksson A, Patra K, Jonsson J, et al. Conditional targeting of medium spiny neurons in the striatal matrix. Front Behav Neurosci. 2015;9:71.
249. Abboud D, Daly AF, Dupuis N, Bahri MA, Inoue A, Chevigné A, et al. GPR101 drives growth hormone hypersecretion and gigantism in mice via constitutive activation of $\mathrm{Gs}$ and $\mathrm{Gq} / 11$. Nat Commun. 2020;11:4752.

250. Lin X, Li M, Wang N, Wu Y, Luo Z, Guo S, et al. Structural basis of ligand recognition and self-activation of orphan GPR52. Nature. 2020;579:152-7.

251. Lobo MK, Cui Y, Ostlund SB, Balleine BW, William Yang X. Genetic control of instrumental conditioning by striatopallidal neuron-specific S1P receptor Gpr6. Nat Neurosci. 2007;10:1395-97.

252. Shrader SH, Song Z-H. Discovery of endogenous inverse agonists for $\mathrm{G}$ protein-coupled receptor 6. Biochem Biophys Res Commun. 2020;522:1041-45.

253. Sartorius A, Henn FA. Deep brain stimulation of the lateral habenula in treatment resistant major depression. Med Hypotheses. 2007;69:1305-08.

254. Antolin-Fontes B, Li K, Ables JL, Riad MH, Görlich A, Williams $\mathrm{M}$, et al. The habenular G-protein-coupled receptor 151 regulates synaptic plasticity and nicotine intake. Proc Natl Acad Sci. 2020;117:5502-09.

255. Broms J, Grahm M, Haugegaard L, Blom T, Meletis K, Tingström A. Monosynaptic retrograde tracing of neurons expressing the G-protein coupled receptor Gpr151 in the mouse brain. J Comp Neurol. 2017;525:3227-50.

256. Broms J, Antolin-Fontes B, Tingström A, Ibañez-Tallon I. Conserved expression of the GPR151 receptor in habenular axonal projections of vertebrates. J Comp Neurol. 2015;523:359-80.

257. Sjöstedt E, Zhong W, Fagerberg L, Karlsson M, Mitsios N, Adori $\mathrm{C}$, et al. An atlas of the protein-coding genes in the human, porcine and mouse brain. Science. 2020;367:eaay5947.

258. Kobayashi Y, Sano Y, Vannoni E, Goto H, Ikeda T, Suzuki H, et al. Genetic dissection of medial habenula-interpeduncular nucleus pathway function in mice. Front Behav Neurosci. 2013;7:17.

259. Liu Z, Xu Y, Wu L, Zhang S. Evolution of galanin receptor genes: insights from the deuterostome genomes. J Biomol Struct Dyn. 2010;28:97-106.

260. Mashiko M, Kurosawa A, Tani Y, Tsuji T, Takeda S. GPR31 and GPR151 are activated under acidic conditions. J Biochem. 2019;166:317-22.

261. Sutton LP, Orlandi C, Song C, Oh WC, Muntean BS, Xie K, et al. Orphan receptor GPR158 controls stress-induced depression. Elife. 2018;7:e33273.

262. Orlandi C, Posokhova E, Masuho I, Ray TA, Hasan N, Gregg $\mathrm{RG}$, et al. GPR158/179 regulate $\mathrm{G}$ protein signaling by controlling localization and activity of the RGS7 complexes. J Cell Biol. 2012;197:711-19.

263. Song C, Orlandi C, Sutton LP, Martemyanov KA. The signaling proteins GPR158 and RGS7 modulate excitability of L2/3 pyramidal neurons and control A-type potassium channel in the prelimbic cortex. J Biol Chem. 2019;294:13145-57.

264. Belzeaux R, Gorgievski V, Fiori LM, Lopez JP, Grenier J, Lin R, et al. GPR56/ADGRG1 is associated with response to antidepressant treatment. Nat Commun. 2020;11:1635.

265. Valverde O, Célérier E, Baranyi $M$, Vanderhaeghen $P$, Maldonado R, Sperlagh B, et al. GPR3 receptor, a novel actor in the emotional-like responses. PLoS ONE. 2009;4:e4704.

266. Eggerickx D, Denef JF, Labbe O, Hayashi Y, Refetoff S, Vassart $\mathrm{G}$, et al. Molecular cloning of an orphan G-protein-coupled receptor that constitutively activates adenylate cyclase. Biochem J. 1995;309:837-43.

267. Zhang LL, Wang JJ, Liu Y, Lu XB, Kuang Y, Wan YH, et al. GPR26-deficient mice display increased anxiety- and depressionlike behaviors accompanied by reduced phosphorylated cyclic AMP responsive element-binding protein level in central amygdala. Neuroscience. 2011;196:203-14. 
268. Tanaka S, Miyagi T, Dohi E, Seki T, Hide I, Sotomaru Y, et al. Developmental expression of GPR3 in rodent cerebellar granule neurons is associated with cell survival and protects neurons from various apoptotic stimuli. Neurobiol Dis. 2014;68:215-27.

269. Miyagi T, Tanaka S, Hide I, Shirafuji T, Sakai N. The subcellular dynamics of the Gs-linked receptor GPR3 contribute to the local activation of PKA in cerebellar granular neurons. PLoS ONE. 2016;11:e0147466.

270. Lee DK, Lynch KR, Nguyen T, Im DS, Cheng R, Saldivia VR, et al. Cloning and characterization of additional members of the $\mathrm{G}$ protein- coupled receptor family. Biochim Biophys Acta Gene Struct Expr. 2000;1490:311-23.

271. Ehrlich AT, Maroteaux G, Robe A, Venteo L, Nasseef MT, van Kempen LC, et al. Expression map of 78 brain-expressed mouse orphan GPCRs provides a translational resource for neuropsychiatric research. Commun Biol. 2018;1:102.

272. Laun AS, Song ZH. GPR3 and GPR6, novel molecular targets for cannabidiol. Biochem Biophys Res Commun. 2017;490:17-21.

273. Kostenis E. Novel clusters of receptors for sphingosine-1phosphate, sphingosylphosphorylcholine, and (lyso)-phosphatidic acid: new receptors for 'old' ligands. J Cell Biochem. 2004;92:923-36.

274. Uhlenbrock K, Gassenhuber H, Kostenis E. Sphingosine 1phosphate is a ligand of the human gpr3, gpr6 and gpr12 family of constitutively active $\mathrm{G}$ protein-coupled receptors. Cell Signal. 2002;14:941-53.

275. Boyden ES, Zhang F, Bamberg E, Nagel G, Deisseroth K. Millisecond-timescale, genetically targeted optical control of neural activity. Nat Neurosci. 2005;8:1263-68.

276. Armbruster BN, Li X, Pausch MH, Herlitze S, Roth BL. Evolving the lock to fit the key to create a family of $G$ proteincoupled receptors potently activated by an inert ligand. Proc Natl Acad Sci. 2007;104:5163-68.

277. Pei Y, Dong S, Roth BL. Generation of designer receptors exclusively activated by designer drugs (DREADDs) using directed molecular evolution. Curr Protoc Neurosci. 2010; Chapter 4.

278. Pei Y, Rogan SC, Yan F, Roth BL. Engineered GPCRs as tools to modulate signal transduction. Physiology. 2008;23:313-21.
279. Nichols CD. Engineered G-protein coupled receptors are powerful tools to investigate biological processes and behaviors. Front Mol Neurosci. 2009;2:16.

280. Muir J, Lopez J, Bagot RC. Wiring the depressed brain: optogenetic and chemogenetic circuit interrogation in animal models of depression. Neuropsychopharmacology. 2019;44:1013-26.

281. Greengard P. The neurobiology of slow synaptic transmission. Science. 2001;294:1024-30.

282. Alexander GM, Rogan SC, Abbas AI, Armbruster BN, Pei Y, Allen JA, et al. Remote control of neuronal activity in transgenic mice expressing evolved $G$ protein-coupled receptors. Neuron. 2009;63:27-39.

283. Zhong P, Liu X, Zhang Z, Hu Y, Liu SJ, Lezama-Ruiz M, et al. Cyclin-dependent kinase 5 in the ventral tegmental area regulates depression-related behaviors. J Neurosci. 2014;34:6352-66.

284. Perova Z, Delevich K, Li B. Depression of excitatory synapses onto parvalbumin interneurons in the medial prefrontal cortex in susceptibility to stress. J Neurosci. 2015;35:3201-6.

285. Carreno FR, Donegan JJ, Boley AM, Shah A, DeGuzman M, Frazer A, et al. Activation of a ventral hippocampus-medial prefrontal cortex pathway is both necessary and sufficient for an antidepressant response to ketamine. Mol Psychiatry. 2016;21: 1298-308.

286. Han S, Yang SH, Kim JY, Mo S, Yang E, Song KM, et al. Down-regulation of cholinergic signaling in the habenula induces anhedonia-like behavior. Sci Rep. 2017;7:900.

287. Sachs BD, Ni JR, Caron MG. Brain 5-HT deficiency increases stress vulnerability and impairs antidepressant responses following psychosocial stress. Proc Natl Acad Sci USA. 2015;112: 2557-62.

288. Teissier A, Chemiakine A, Inbar B, Bagchi S, Ray RS, Palmiter $\mathrm{RD}$, et al. Activity of Raphé serotonergic neurons controls emotional behaviors. Cell Rep. 2015;13:1965-76.

289. Galvan A, Caiola MJ, Albaugh DL. Advances in optogenetic and chemogenetic methods to study brain circuits in non-human primates. J Neural Transm. 2018;125:547-63.

290. Kay MA. State-of-the-art gene-based therapies: the road ahead. Nat Rev Genet. 2011;12:316-28. 